Universidade de Brasília

Centro de Excelência em Turismo

\title{
GRADUAÇÃO EM TURISMO NO DISTRITO FEDERAL: Um exame dos Currículos à luz das Diretrizes Curriculares Nacionais
}

\author{
Walméria Rodrigues da Cunha e Faria \\ Matrícula 2003/00021 - Turma B \\ Prof. MSc Domingos Sávio Spezia
}

Monografia apresentada ao Centro de Excelência em Turismo da Universidade de Brasília como requisito parcial para a obtenção do certificado de Especialista em Formação de Professores e Pesquisadores em Turismo e Hospitalidade. 


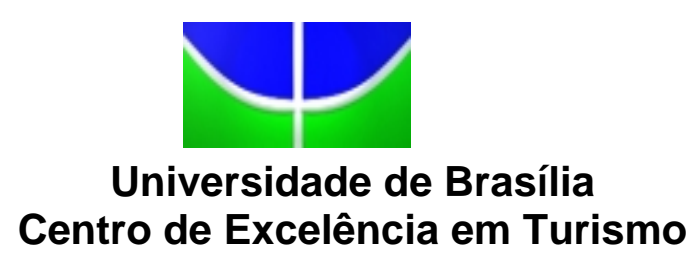

Curso de Formação para professores e pesquisadores em turismo e hospitalidade

GRADUAÇÃO EM TURISMO NO DISTRITO FEDERAL: Um exame dos Currículos à luz das Diretrizes Curriculares Nacionais

Walméria Rodrigues da Cunha e Faria

Banca Examinadora

Prof'o Ms. Domingos Sávio Spezia

Orientador

\section{Membro da Banca}

Profa Dra. Tânia Siqueira Montoro 
Walméria Rodrigues da Cunha e Faria

\title{
GRADUAÇÃO EM TURISMO NO DISTRITO FEDERAL: Um exame dos Currículos à luz das Diretrizes Curriculares Nacionais
}

\author{
Comissão Avaliadora
}

Prof $^{\circ}$ Ms. Domingos Sávio Spezia

Orientador

\section{Prof $^{a}$ Dra. Tânia Siqueira Montoro \\ Prof $^{a}$ Examinadora}




\section{DEDICATÓRIA}

Dedico este trabalho aos meus amigos: velhos amigos, novos amigos, amigos conquistados, amigos distantes e amigos amigos. 


\section{AGRADECIMENTOS}

Agradeço a Deus e a todas as pessoas que direta ou indiretamente contribuíram para a realização deste trabalho, à Universidade de Brasília, ao PROCAP e ao Centro de Excelência em Turismo pelo apoio; aos meus filhos Pedro e Fernanda por compreenderem minha ausência e ao meu Orientador Profo Domingos Spezia por me acolher e me ajudar. 


\section{RESUMO}

O Turismo é uma atividade que vem crescendo nos últimos anos, abrangendo pessoas, lugares, empresas, economia, conhecimento técnico e científico, e, principalmente, o lazer e o ócio. A qualificação dada pela Academia ao turismo é discutida neste trabalho por meio de levantamento dos marcos legais que regem a educação brasileira, e, especificamente, a importância da formação profissional para o desenvolvimento do turismo no Distrito Federal. A base da pesquisa utilizada foi o conjunto de faculdades de turismo do Distrito Federal. São discutidas questões acerca da importância do perfil desejado dos educandos e da estrutura dos cursos de graduação em turismo, evidenciando a importância da permanente reflexão sobre a multiplicidade de conhecimentos que envolvem a área com o objetivo de otimizar e potencializar a qualidade dos cursos, indiretamente dos serviços turísticos. 


\begin{abstract}
Tourism is an activity which has grown in recent years, involving people, places, enterprises, the economy, technological and scientific knowledge and most of all, the right to leisure.The professional training provided by higher education in tourism is discussed in this work by means of a survey of the relevant sections of the Brazilian legislation on education, and, in particular, the importance of professional training for the development of tourism in the Distrito Federal. The base for the research was the group of higher education tourism schools in the Distrito Federal. The work discusses the importance of the profile sought for the students and for the undergraduate courses in tourism, pointing out the importance of the need for a permanent reflection on the multiplicity of knowledge subjects involved in the area, with the objective to optimize the quality of the courses and indirectly the tourism services.
\end{abstract}


S U M Á R I O

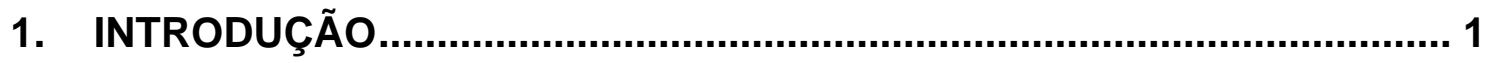

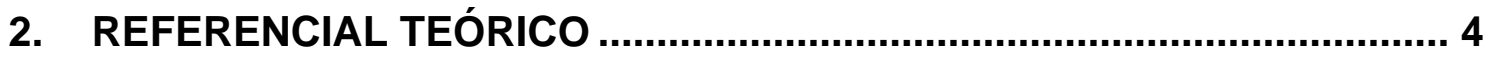

2.1. LEI DE DIRETRIZES E BASES DA EDUCAÇÃO ...................................... 4

2.2. DIRETRIZES CURRICULARES NACIONAIS ..................................... 6

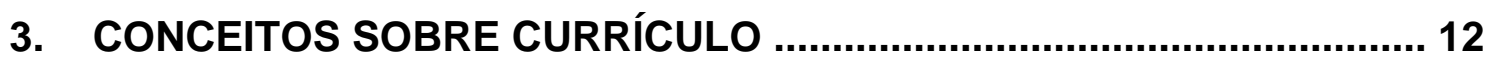

4. A IMPORTÂNCIA DA FORMAÇÃO PROFISSIONAL NO TURISMO ..... 14

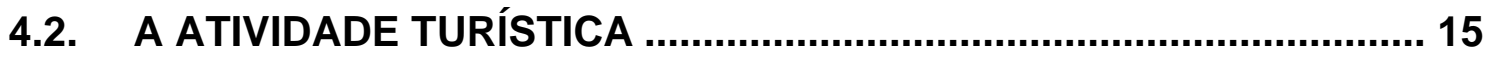

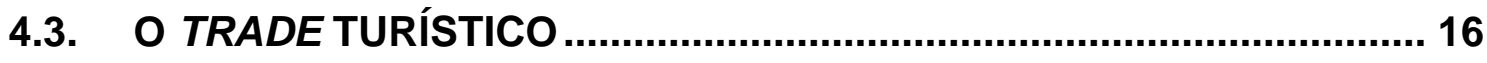

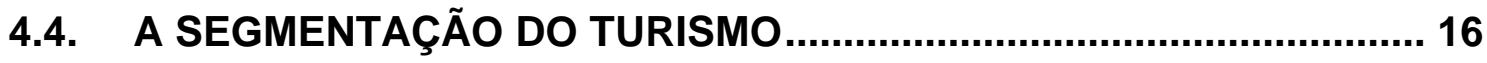

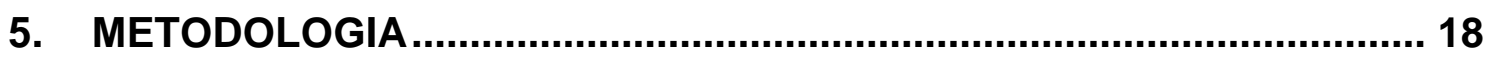

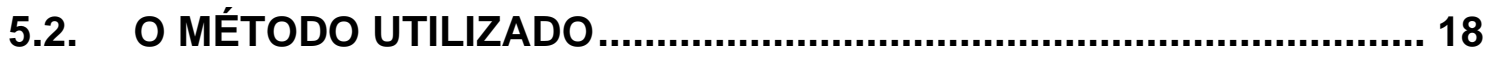

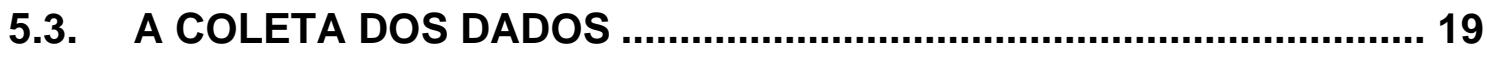

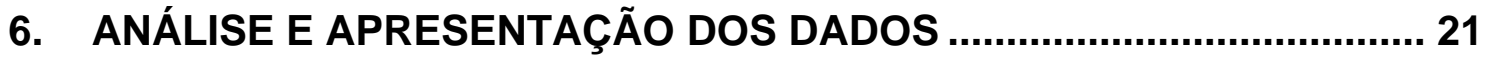

6.2. MATRIZ COMPARATIVA DOS CURSOS DE GRADUAÇÃO EM

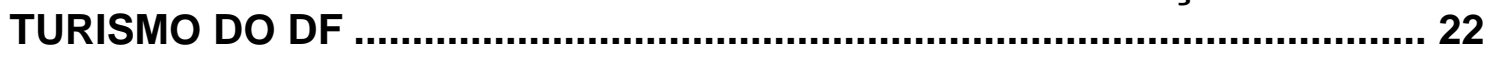

6.3. GRADE DOS CURSOS DE GRADUAÇÃO EM TURISMO DO DF ...... 24

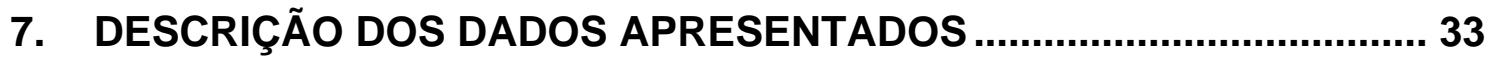

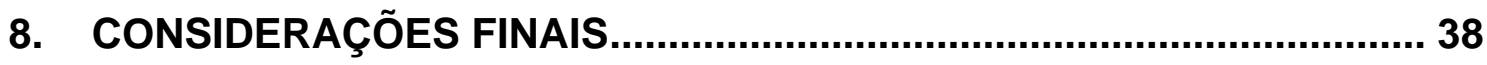

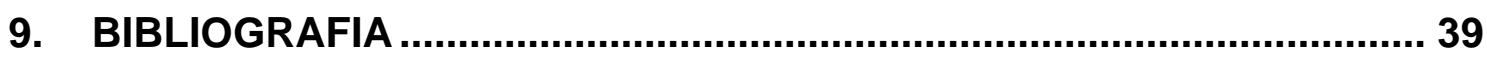

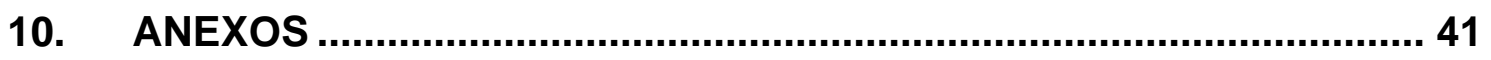




\section{LISTA DE ABREVIATURAS}

ABAV Associação Brasileira de Viagens ABBTUR Associação Brasileira de Bacharéis e Estudantes de Turismo ABDETH Assoc. Bras. de Dirigentes de Escolas de Turismo e Hotelaria ABRE Associação Brasileira de Restaurantes CECAP Centro de Empreendedorismo e Capacitação Profissional CES .Conselho de Educação Superior CESUBRA .Centro de Ensino Superior Unificado de Brasília CET. Centro de Excelência em Turismo

CNE Conselho Nacional de Educação CNEC. Fac. Cenecista de Brasília EMBRATUR. Instituto Brasileiro de Turismo FTB .Faculdade da Terra de Brasília IESB. Instituto de Educação Superior de Brasília MEC Ministério da Educação

OMT Organização Mundial do Turismo

ONU Organização das Nações Unidas SEBRAE. Serviço de Apoio às Micro e Peq. Empresas SESU Secretaria de Educação Superior SETUR Secretaria de Turismo UniCEUB Centro Universitário de Brasília UNIP. ...Universidade Paulista UPIS. União Pioneira de Integração Social - Faculdades Integradas 


\section{INTRODUÇÃO}

Os cursos de bacharelado em Turismo são relativamente recentes no país, comparados com outras áreas do conhecimento. A Universidade AnhenbiMorumbi, pioneira na área, abriu sua primeira turma em 1971. Na época, o turismo mal se delineava, no cenário econômico-empresarial como fenômeno social e como político setorial, cujo crescimento estimulou a abertura de cursos. Hoje, os cursos de Turismo em nível de bacharelado totalizam mais de quatrocentos em todo o país. No Distrito Federal, 10 faculdades oferecem o curso de bacharelado em Turismo.

Pouco a pouco as matrizes curriculares assumiram características distintas que foram surgindo de acordo com as necessidades e as demandas de cada região. Atualmente no Brasil, apenas o estado de Roraima não oferece curso de bacharelado em Turismo.

Após o surgimento dos primeiros cursos de turismo, surge a Lei no 9.394 , de 20 de dezembro de 1996, que estabelece as Diretrizes e Bases da Educação Brasileira e o Plano Nacional de Educação (Lei 10.172/2001).

A Lei de Diretrizes e Bases propõe a progressiva implantação dos currículos de forma flexível, visando à autonomia das instituições de ensino, ratificando o seu caráter flexibilizador do sistema educacional.

Para assegurar e controlar a qualidade da formação oferecida pelas Instituições de Ensino Superior, o MEC, por intermédio da Secretaria de Ensino Superior - SESu, confere autonomia às Instituições de Ensino Superior na definição dos currículos de seus cursos.

A partir da explicitação das competências e habilidades, que se deseja desenvolver, por meio da organização de um modelo pedagógico capaz de adaptar-se à dinâmica das demandas da sociedade, e uma vez que a graduação passa a constituir-se numa etapa de formação inicial no processo contínuo de educação permanente, propõe-se uma carga horária mínima em horas que permita flexibilização do tempo de duração do curso de acordo com a disponibilidade e esforço do aluno e do desenho curricular.

Prevê-se a estruturação modular dos cursos com vistas a permitir um melhor aproveitamento dos conteúdos ministrados, bem como a ampliação da 
diversidade da organização dos cursos. Contemplam-se as orientações para as atividades de estágio e demais atividades que integrem o saber acadêmico à prática profissional, incentivando o reconhecimento de habilidades $\mathrm{e}$ competências adquiridas fora do ambiente escolar.

As discussões para a sistematização das Diretrizes Curriculares nas IES começaram no final de 1997. A SESu iniciou uma série de atividades que tiveram início a partir de 1997 com a publicação do Edital 4/97, que convocou as Instituições de Ensino Superior a apresentarem propostas para as diretrizes curriculares dos cursos de graduação em todas as áreas do conhecimento.

De acordo com as Diretrizes Curriculares do Ministério da Educação - MEC, parecer do CNE/CES-146/2002, e, por último, o Parecer CNE/CES-288/2003, que aguarda homologação do Ministro da Educação, o Curso de bacharelado em Turismo deve preparar profissionais para atuarem no planejamento, gestão, pesquisa e docência na área de turismo, tendo como foco o turismo como fenômeno socioeconômico.

A formação do bacharel em Turismo são destinadas 2.520 horas mínimas aproveitadas com disciplinas oriundas do conteúdo básico e dos conteúdos específicos, acrescidas de 480 horas mínimas aproveitadas com disciplinas de conteúdo específico-profissional. A proposta deixa a critério das IES a duração máxima, devendo levar em conta, na integralização, as diferentes possibilidades de formação específica.

Em geral, entende-se que o ensino tem qualidade se o aluno estiver apto, após o término do curso, a executar as tarefas necessárias ao exercício da sua profissão. Se a Instituição de Ensino Superior atender às empresas e à sociedade com profissionais que satisfaçam esses requisitos, haverá a percepção de que a qualidade do ensino é realmente "muito boa".

Ao abordar o presente tema, surgem questões prementes sobre a graduação, tomando como objeto de análise as grades curriculares dos cursos de turismo no DF. O que os cursos de turismo do DF abordam em seus currículos? Que tipo de profissional as faculdades do DF estão formando para o mercado de trabalho em Turismo? Como se comportam as IES frente às diretrizes curriculares para os cursos de turismo?

Objetivando realizar uma análise documental e aplicada dos currículos, ementas, programas, grades e regimentos das faculdades de turismo do DF, 
foram levantados os dados a partir de informações obtidas por meio de visitas e entrevistas, que complementaram a trajetória metodológica utilizada nesta monografia, com o intuito de: 1) realizar um estudo comparativo entre currículos de graduação dos cursos de Turismo das Instituições de ensino superior do DF; 2) identificar se as Instituições de Ensino Superior estão cumprindo as diretrizes e formando profissionais que atendam adequadamente ao mercado de trabalho e a sociedade no DF e 3) identificar o perfil do educando que ingressa no mercado de trabalho em turismo.

Dessa forma, o presente trabalho constitui-se numa análise dos currículos dos cursos de graduação em Turismo do DF, tendo como base a LDB e as Diretrizes Curriculares dos cursos de graduação em Turismo proposta pelo Ministério da Educação. O objetivo precípuo é investigar qual o perfil do profissional que está sendo formado nos cursos de graduação em turismo no DF.

O trabalho está estruturado da seguinte forma: Introdução, resumo, algumas reflexões à luz da LDB/96 e das Diretrizes Curriculares para os cursos de graduação em Turismo, tratando da importância da formação profissional no turismo, da natureza da atividade turística, do trade turístico no DF. Aborda também a necessidade da formação de profissionais em diversas áreas e segmentos do turismo, as perspectivas de parcerias no DF que capacitem os profissionais, empreendedores, empresários, pesquisadores, professores e promovam o desenvolvimento do setor de turismo no DF; o mercado de trabalho no DF; a descrição da análise dos resultados sobre a coleta de dados documentais nas 10 (dez) instituições de ensino do DF e entrevistas realizadas com coordenadores do curso de graduação em Turismo das Faculdades Euroamericana, IESB e UniCEUB, destacando os pontos principais das Diretrizes Curriculares Nacionais para os cursos de Turismo, o parecer CES/CNE 0288/2003, considerações finais, bibliografia e, por fim, os anexos contendo as entrevistas. 


\section{REFERENCIAL TEÓRICO}

\subsection{LEI DE DIRETRIZES E BASES DA EDUCAÇÃO}

A Lei $\mathrm{n}^{\circ}$ 9.394/96, promulgada em 20 de dezembro de 1996, sancionada pelo presidente Fernando Henrique Cardoso e publicada no Diário Oficial da União em 23 de dezembro de 1996, estabeleceu novas diretrizes e bases da educação nacional. Percorreu, até esse momento, um longo e árduo caminho com ganhos e perdas. ${ }^{1}$

Após aprovação da Constituição de $1988^{2}$, são iniciadas as discussões em torno do novo projeto de Lei de Diretrizes e Bases da Educação Nacional. A primeira proposta a tramitar na Câmara Federal foi o Projeto de Lei no 1.258-A/88, apresentado em dezembro de 1988 pelo deputado Octávio Elísio. O conteúdo desse projeto foi intelectualmente estudado e elaborado pelo pesquisador Demerval Saviani em fevereiro de 1988.

Em 1989, foi constituído o Grupo de trabalho da LDB, presidido por Florestan Fernandes e tendo como relator Jorge Hage. Terminados os trabalhos em junho de 1990, o texto foi aprovado na Comissão de Educação, Cultura e Desporto da Câmara dos Deputados e transformando em Substitutivo da Comissão, também conhecido por Substitutivo Jorge Hage, a fim de prosseguir sua trajetória no Congresso Nacional. O substitutivo Jorge Hage alterou profundamente a estrutura e o conteúdo da proposta inicial do projeto de lei do deputado Octávio Elísio.

Resumidamente, a trajetória percorrida pelas propostas até a aprovação da nova LDB, em 1996, foi a seguinte: $1^{\circ}$ ) o Substitutivo Jorge Hage é aprovado no segundo semestre de 1990 na comissão de Justiça; $2^{\circ}$ ) segue para discussão no plenário da Câmara dos Deputados no primeiro semestre de 1991; $3^{\circ}$ ) retorna às comissões, onde fica até o primeiro semestre de 1993; $4^{\circ}$ ) Concomitantemente, é dada a entrada do projeto do senador Darcy Ribeiro na Comissão de Educação do Senado, em maio de 1992, para discussão; $5^{\circ}$ ) esse projeto é provisoriamente

\footnotetext{
1 A análise histórica da elaboração da Lei pode ser apreciada no livro de Saviani intitulado A nova lei da educação:Trajetória, limites e perspectivas

2 A Constituição da República Federativa do Brasil, promulgada em 05 de outubro de 1988, é constituída por nove títulos, trinta e três capítulos, quarenta e nove seções, cinco subseções e duzentos e cinqüenta artigos. As questões relativas à educação estão presentes em 13 artigos que se encontram inseridos no Título VIII, intitulado Da Ordem Social, Capítulo III - Da Educação, da Cultura e do Desporto.
} 
arquivado na Comissão de Educação do Senado. $6^{\circ}$ ) Aprova-se o Projeto de Lei no 1.258/88, em maio de 1993, na Câmara dos Deputados; $7^{\circ}$ ) Posteriormente, é encaminhado para análise e aprovação no Senado Federal, identificado como PLC (Projeto de Lei da Câmara) nº 101 de 1993; 8º O senador Cid Sabóia é nomeado relator do projeto; $9^{\circ}$ ) $\mathrm{O}$ parecer desse senador é aprovado na Comissão de Educação do Senado, em 30 de novembro de 1994, passando a ser designado como Substitutivo no 250 ou, simplesmente, substitutivo Cid Sabóia; $10^{\circ}$ ) Esse substitutivo é encaminhado ao plenário do Senado em 12 de dezembro de 1994; 11º) Em março de 1995, o senador Darcy Ribeiro apresenta - na Comissão de Constituição, Justiça e Cidadania - seu parecer desfavorável ao substitutivo de Cid Sabóia, alegando inconstitucionalidade do PLC n 101/93; 12²) Em fevereiro de 199, é aprovado no plenário do Senado o substitutivo do senador Darcy Ribeiro; $13^{\circ}$ ) O projeto retorna à Câmara dos Deputados para análise; $14^{\circ}$ ) O deputado José Jorge é designado relator do Substitutivo Darcy Ribeiro; $15^{\circ}$ ) Em 17 de dezembro, aprova-se o relatório do deputado José Jorge; e $16^{\circ}$ ) Finalmente, o texto foi para a sanção do Presidente da República e aprovado sem nenhum veto.

Cabe ressaltar que o relatório apresentado pelo relator sobre o substitutivo Darcy Ribeiro manteve a mesma estrutura, introduzindo apenas algumas pequenas alterações no projeto original. No entanto, é possível perceber as lutas travadas que uma lei, quando discutida, põe em campo um embate de forças e traz consigo, portanto, uma série de expectativas e, até mesmo, de esperanças e desafios para todos os sujeitos envolvidos no processo.

Cabe ressaltar, ainda, que qualquer projeto de lei a ser aprovado está permeado de discussões e de tentativas de soluções conciliadoras, mas sempre visando encontrar uma saída que atenda aos interesses de grupos hegemônicos. 


\subsection{DIRETRIZES CURRICULARES NACIONAIS}

O Ministério da Educação (MEC), órgão responsável pela educação no Brasil, por meio da secretaria de ensino superior (SESu), coordenou concomitantemente com o Fórum Nacional de Pró-Reitores de Graduação (ForGrad), a elaboração das propostas de diretrizes curriculares para os cursos de graduação.

Conforme o documento conceitual das Diretrizes, elaborado pelo ForGrad em 1998, os princípios que nortearam a iniciativa de sistematizar as diretrizes curriculares para os cursos de graduação, segundo a Secretaria de Ensino Superior, visavam:

assegurar às instituições de ensino superior ampla liberdade na composição da carga horária a ser cumprida para a integralização dos currículos, assim como na especificação das unidades de estudos a serem ministradas; indicar os tópicos ou campos de estudo e demais experiências de ensino-aprendizagem que comporão os currículos, evitando ao máximo a fixação de conteúdos específicos com cargas horárias pré-determinadas, as quais não poderão exceder $50 \%$ da carga horária total dos cursos; evitar o prolongamento desnecessário da duração dos cursos de graduação; incentiva uma sólida formação geral, necessária para que o futuro graduado possa vir a superar os desafios de renovadas condições de exercício profissional e de produção de conhecimento, permitindo variados tipos de formação e habilidades diferenciadas em um mesmo programa; estimular práticas de estudo independente, visando a uma progressiva autonomia profissional e intelectual do aluno; encorajar o aproveitamento do conhecimento, habilidades e competências adquiridas fora do ambiente escolar, inclusive as que referirem à experiência profissional julgada relevante para a área de formação considerada; fortalecer a articulação da teoria com a prática, valorizando a pesquisa individual e coletiva, assim como os estágios e a participação em atividades de extensão, as quais poderão ser incluídas como parte da carga horária; incluir orientações para a condução de avaliações periódicas que utilizem instrumentos variados e sirvam para informar a docentes e a discentes acerca do desenvolvimento das atividades didáticas.

Nesse sentido, e com o intuito de assegurarem a flexibilidade e a qualidade da formação oferecida pelas Instituições de Ensino Superior, os objetivos almejados pela Secretaria de Ensino Superior, conferiram maior autonomia às IES na definição dos currículos de seus cursos, a partir da explicitação das competências e das habilidades que se deseja desenvolver, por meio da organização de um modelo pedagógico capaz de adaptar-se à dinâmica das demandas da sociedade, em que a graduação passa a constituir-se numa etapa de formação inicial no processo contínuo de educação permanente; propuseram uma carga horária mínima em horas que permita a flexibilização do tempo de duração do curso de acordo com a disponibilidade e o esforço do aluno; 
otimizaram a estruturação modular dos cursos com vistas a permitir um melhor aproveitamento dos conteúdos ministrados, bem como a ampliação da diversidade da organização de cursos, integrando a oferta de cursos seqüenciais, previstos no inciso I do artigo 44 da LDB; contemplaram orientações para as atividades de estágio e demais atividades que integrem o saber acadêmico à prática profissional, incentivando o reconhecimento de habilidades $\mathrm{e}$ competências adquiridas fora do ambiente escolar; contribuir para a inovação e a qualidade do projeto pedagógico do ensino de graduação, norteando os instrumentos de avaliação.

As Diretrizes Curriculares surgiram com o intuito de assegurar que as IES proponham o Currículo em seu sentido mais amplo, isto é, como o conjunto de vivências do aluno no âmbito da Universidade, desde que o aprendizado seja avaliado. O currículo pode ser, portanto, considerado como um conjunto qualquer de atividades acadêmicas previstas pela Universidade para a integralização de um curso. A atividade acadêmica, e não apenas a disciplina, deve ser aquela considerada relevante para que o estudante seja capaz de adquirir, durante a integralização curricular, o saber e as habilidades necessárias a sua formação e que contemple processos avaliativos.

O currículo não deve se restringir a apresentação de um elenco de disciplinas. Deve incorporar elementos da proposta pedagógica de maneira a torná-lo um instrumento de avaliação do processo de ensino e aprendizagem. Os indicativos de que o currículo atende ao aperfeiçoamento do ensino podem ser sumarizados nos seguintes itens:

a) Sintonia entre o perfil que se busca atingir do formando - incluindo as habilidades a serem desenvolvidas, a estruturação das atividades ao longo da permanência do aluno na Instituição de ensino - e a com inserção local, regional, ou internacional da Instituição;

b) Ensino voltado para o aluno, tornando-o sujeito ativo do processo de ensino e aprendizagem;

c) Desenvolvimento e aprimoramento de habilidades cognitivas, afetivas, e de competências formativas do aluno;

d) Valorização do ser humano, dos aspectos sociais e das questões ambientais;

e) Articulação entre pesquisa básica e aplicada;

f) Integração entre teoria e prática; 
g) Articulação do conhecimento da área específica do curso com outros conhecimentos complementares.

O currículo, com as características definidas no item 4, deve apresentar:

a) Flexibilidade de estrutura, permitindo ao aluno diversificar sua formação;

b) Variedade na oferta de tipos de atividades para a integralização curricular, de maneira que incentive o aluno a desenvolver sua capacidade de lidar com problemas e buscar soluções;

c) Articulação entre atividades desenvolvidas pelo aluno no âmbito da Universidade com aquelas de seu campo de atuação profissional;

d) Ênfase nas atividades centradas na criatividade e na capacidade de (re)construir, (re)estruturar, (re)ordenar e buscar novas interpretações às situações propostas.

As diretrizes curriculares devem definir a carga horária referencial para os cursos. Cada IES estabelecerá a carga horária de seus cursos, com base na carga horária referencial, evitando prolongamentos desnecessários ou reduções excessivas.

A autorização de um novo curso, seu reconhecimento ou recredenciamento deve levar em consideração para sua avaliação os seguintes itens do currículo:

a) Se as temáticas propostas e as habilidades a serem desenvolvidas levam à aquisição do perfil de profissional enunciado;

b) Se apresenta flexibilidade em sua estrutura, permitindo ao aluno diversificar sua formação acadêmica;

c) Se o currículo apresenta, em sua estruturação, indicativos de: articulação entre teoria e prática; processo de ensino e aprendizagem centrado no aluno; desenvolvimento de atividades diversificadas com ênfase na utilização de laboratórios e nas atividades de pesquisa e extensão;

d) Se o currículo explicita, na proposta da estrutura curricular, o desenvolvimento das habilidades e competências formativas.

Visando a sistematização dos cursos de graduação ofertados pelas Instituições de Ensino Superior, implementou-se uma série de atividades, que tiveram início do ano de 1997, e que pode ser dividida em três fases distintas e complementares. 
A primeira fase constituiu-se, basicamente, de duas atividades: Primeiramente, a publicação do Edital 4/97, que convocou as Instituições de Ensino Superior a apresentarem propostas para as diretrizes curriculares dos cursos de graduação; posteriormente, a organização de seminários e encontros destinados a discutir as propostas - tendo o Fórum Nacional de Pró-Reitores de Graduação como Vice-Presidente o Prof. Dr. Fernando Jorge Rodrigues Neves, Decano de Ensino de Graduação da Universidade de Brasília, e na gestão seguinte 1999/2000, como Presidente do Fórum - adquirido, assim, importância fundamental no processo de discussões. O resultado dessa primeira fase do processo de sistematização das diretrizes curriculares dos cursos de graduação foi o recebimento de aproximadamente mil e duzentas propostas, oriundas em sua grande maioria da comunidade acadêmica.

A segunda fase do processo teve início com a convocação das Comissões de Especialistas de Ensino (CEEs) que, de posse das sugestões apresentadas, foram incumbidos de produzir as propostas definitivas para serem encaminhadas para análise do Conselho Nacional de Educação ${ }^{3}$.

As propostas de diretrizes curriculares, elaboradas pelas comissões de especialistas de ensino, passam a ser denominadas a partir desse momento de modelo de enquadramento, e foram posteriormente submetidas à apreciação de consultores ad hoc em cada área de conhecimento. Assim, a partir de dezembro de 1998, as primeiras propostas foram sendo encaminhadas para análise do Conselho Nacional de Educação, sendo agrupadas em grandes áreas de conhecimento, segundo critérios utilizados pela Coordenação de Aperfeiçoamento de Pessoal de Nível Superior (Capes).

A terceira e última fase do processo constitui-se da aprovação e da homologação das diretrizes curriculares pelo Conselho Nacional de Educação.

O parecer CNE/CES No 583/2001 - que trata da orientação para as diretrizes curriculares dos cursos de graduação - foi aprovado por unanimidade na Câmara de Educação Superior em sessão do dia 04 de abril de 2001.

\footnotetext{
${ }^{3}$ O Conselho Nacional de Educação (CNE) é composto por duas câmaras autônomas: a Câmara de Educação Superior e a Câmara de Educação Básica. O CNE reúne-se como Conselho Pleno, ordinariamente, a cada dois meses e suas câmaras reúnem-se mensalmente. Atualmente, apresenta a seguinte composição: presidente do Conselho Pleno, presidente da Câmara de Educação Básica, presidente da Câmara de Educação Superior, vice-presidente da Câmara de Educação Básica, vice-presidente da Câmara de Educação Superior.
} 
Realizada essa breve descrição sobre a metodologia de trabalho adotada pela Secretaria de Ensino Superior do Ministério da Educação para elaboração das propostas de diretrizes curriculares para os cursos de graduação, far-se-á análise específica das propostas elaboradas para os cursos de Turismo.

A Diretriz Curricular para os cursos de Turismo, entregue ao Conselho Nacional de Educação, foi elaborada pelos Membros da Comissão de Especialistas de Ensino, nomeados para elaborar a proposta curricular dos cursos de Turismo, a qual propõe e afirma que o profissional a ser formado pelos cursos de bacharelado em Turismo deve possuir uma sólida formação, que contemple aspectos teóricos, práticos e éticos, visando ao desenvolvimento de competências e habilidades gerais, a fim de que tal profissional exerça de "forma competente" suas funções.

O primeiro documento elaborado pelo Conselho Nacional de Educação foi o parecer CNE/CES 146/200, homologado pelo Ministro da Educação em 09/05/2002 e publicado no Diário Oficial da União no 90, de 13/05/2002, Seção 1.

Tramita, no Conselho Federal de Educação, novo parecer CNE/CES no 0288/2003, sistematizado pelas Comissões de Especialistas de Ensino da área de turismo, aprovado em 6/11/2003 e sujeito a homologação do Ministro da Educação.

Determinadas diretrizes podem ser consideradas comuns aos cursos de graduação, enquanto outras atendem à natureza e às peculiaridades de cada curso, desde que contemplem as alíneas seguintes que tratam das principais competências e habilidades do profissional:

- Perfil do formando;

- Competências /habilidades/atitudes;

- Habilitações e ênfase;

- Componentes e conteúdo curriculares;

- O estágio e as atividades complementares;

- Acompanhamento e avaliação;

- Estágios e atividades complementares.

O perfil desejado do profissional a ser formado nos cursos de bacharelado em Turismo é aquele que proporcione uma formação generalista e 
particularizada, ou seja, um profissional com conhecimentos gerais e habilidades técnicas necessários ao exercício de suas funções, apto para atuar em um mercado competitivo e em constante transformação. 


\section{CONCEITOS SOBRE CURRÍCULO}

Segundo Lord Curson", "O turismo é uma Universidade em que o aluno nunca se gradua, é um Templo onde o suplicante cultua mas nunca vislumbra a imagem de sua veneração, é uma Viagem com destino sempre à frente mas jamais atingido. Haverá sempre contempladores, sempre errantes aventureiros" .

Segundo Cunha (1998), " Currículo é um programa educacional que deve ser elaborado com base em princípios que orientam suas quatro fases básicas: a seleção dos objetivos, a seleção das experiências de aprendizagem, a organização das experiências de aprendizagem e a avaliação".

Tyler (2001) afirma que "Currículo é um programa educacional que deve ser planejado com base em princípios racionais para ser bom, ou seja, a qualidade do currículo está implícita em sua racionalidade e instrumentalidade que o tornam bom, quando feito com princípios concatenados. Estes princípios são concatenados de um modo lógico, mas esta logicidade tem uma função programática, no sentido de embasar o como planejar".

Os currículos dos cursos de graduação, segundo orientações do Ministério da Educação e do Conselho Federal de Educação, podem ter os formatos Pleno e Padrão.

A grade de disciplinas, segundo o currículo mínimo de Turismo estabelecido pela Resolução s/no de 1971 do CFE, e as propostas de Diretrizes Curriculares para os Cursos de Turismo e de Hotelaria, devem conter flexibilidade curricular no número de créditos e carga horária por disciplina; o quadro-resumo total de horas e do percentual de disciplinas de formação específica, complementar e estágio supervisionado; o ementário e o programa de disciplinas com bibliografia básica.

Entender-se-á por Currículo-Pleno de um curso o conjunto das disciplinas integrantes das matérias de currículo mínimo e das disciplinas obrigatórias e optativas.

Entender-se-á por Currículo-Padrão de um curso o conjunto de estudos e atividades correspondentes a um programa desenvolvido em um período, com uma carga horária pré-fixada.

4 Lord Curson (1859-1925) Governador-geral da Índia - Citado no livro Análise Estrutural doTurismo, Mário Carlos Beni, pp 15, 2001 
A distribuição das disciplinas no currículo-padrão de um curso será por períodos letivos semestrais. Podem ser organizados conforme a conveniência de cada IES, da seguinte forma:

a) A organicidade de um currículo poderá ser delineada por meio da adequada articulação das disciplinas em termos de períodos;

b) A distribuição das disciplinas nos períodos letivos deverá expressar a ordenação desejável, o grau de dificuldade e a concomitância entre os conteúdos;

c) A disciplina, cujo conteúdo for imprescindível ao desenvolvimento de outra, figurará, no currículo, como pré-requisito.

A alteração curricular poderá ser realizada pelas instâncias superiores do curso sempre que necessário. É um processo que visa a promover ajustes, tais como: alteração de carga horária, modificação de pré-requisito das disciplinas, criação ou extinção de disciplinas optativas e reordenação do currículo-padrão.

Esta alteração consiste na adequação ao mercado de trabalho e ao grau de desenvolvimento da área do conhecimento, a que se referem os conteúdos; detalhamento dos pontos de estrangulamento e da alteração de perspectiva institucional; indicação dos processos utilizados para se obter essa avaliação.

De acordo com as Diretrizes Curriculares ${ }^{5}$, a organização curricular das instituições de ensino superior deve exercitar seu potencial inovador e criativo e da liberdade e flexibilidade que possuem na organização de seus currículos, devem concebê-los de acordo com os regimes acadêmicos que adotarem, os sistemas de pré-requisitos e de créditos por disciplina, prevendo expressamente a integralização curricular do curso como condição para a sua efetiva conclusão e subseqüente colação de grau, com distribuição de tempo útil previsto, definido em termos de carga horária, duração ou redução de duração de curso, de tal forma que os alunos tenham a informação do tempo de estudos previsto e das possibilidades de redução ou ampliação desse tempo, preservando o princípio de padrão de qualidade.

\footnotetext{
${ }^{5}$ Diretrizes curriculares, parecer CNE/CES №288/2003 - Ministério da Educação
} 


\section{A IMPORTÂNCIA DA FORMAÇÃO PROFISSIONAL NO TURISMO}

Não há cursos de graduação em Turismo na Universidade de Brasília, a única Instituição de Ensino Superior público no Distrito Federal. Os cursos de Turismo no DF são ministrados nas faculdades particulares: Caiçaras, CECAP, CNEC, Euro-Americana, FTB, IESB, UNIP/CESUBRA, UPIS e UniCEUB.

O Bacharel em Turismo, segundo a ABBTUR, é um profissional egresso dos cursos superiores de Turismo que foram implantados, no Brasil, a partir dos anos 70. Sua formação é de nível superior na área das ciências humanas. Por meio da sua formação universitária, o profissional adquire a capacidade de análise crítica, reflexão e torna-se um agente de transformação da atividade através de pesquisas e estudos afins. Com o desenvolvimento da atividade turística e do comportamento contemporâneo, os consumidores tornaram-se mais exigentes com relação à prestação de serviços da atividade turística e a mão-de-obra especializada passou a ser um componente fundamental do fator qualidade, sendo o Bacharel em Turismo um importante componente da oferta dos serviços de turismo.

O curso de Turismo é recente no Brasil. Firmou-se na década de 90, mas, antes mesmo deste período, discussões em torno do assunto já atingiram nível nacional. Por ser um curso multidisciplinar, profissionais de diversas áreas preocupam-se com a educação em turismo.

As discussões tomaram força e com vistas a subsidiar as novas diretrizes curriculares a serem apreciadas pelo MEC, baseadas na nova Lei de Diretrizes e Bases (LDB) que fora aprovada em 1996 da qual se tratou no item 2.2 desta monografia, realizou-se um encontro Nacional de Bacharéis e Estudantes de Turismo (Enbetur), organizado pela ABBTUR em São Paulo, e vários outros encontros da ABDETH.

Há um ponto em comum na literatura internacional existente sobre teoria em turismo: o consenso sobre a necessidade de a educação direcionada à área ser muito bem estruturada e baseada em fundamentos amplamente discutidos e aceitos pela comunidade empresarial, acadêmica e política. 
O World Travel and Tourism Review, em sua pauta sobre os desafios de uma política turística global para os anos 90, elenca dez itens principais e nove itens emergentes para discussão. Três desses itens referem-se à educação e à cultura relacionadas ao turismo. São eles:

1. A diversidade cultural deve ser reconhecia no contexto da sociedade global.

2. O problema dos recursos humanos. Há uma necessidade contínua e crescente de incremento do número de pessoal especializado na área e de aprimoramento de seu profissionalismo, nos seguintes pontos em particular:

a) Priorização de programas de educação e treinamento em turismo em todos os níveis;

b) encorajamento de todos os setores da indústria turística para a cooperação ativa no desenvolvimento e no treinamento em programas educacionais, a fim de assegurar que esses programas preencham as necessidades de um mercado diversificado, particularmente em relação às necessidades especiais de áreas envolvidas com multiculturalismo, faixas etárias e outros segmentos;

c) promoção da integração de conteúdos turísticos ao sistema educacional público de uma forma geral;

d) possibilidade de treinamento, educação e inserção dos trabalhadores e dirigentes nativos nas áreas turísticas.

3. Os avanços tecnológicos possibilitam oportunidades e pressionam a melhoria do desempenho produtivo, do desenvolvimento de recursos humanos e a reestruturação da indústria turística. (1991: p. 153 e 156)

\subsection{A Atividade Turística}

Hoje se fala em indústria do turismo, em virtude do setor movimentar recursos que colocam a atividade turística no mercado internacional. Dados divulgados pela OMT, organismo ligado à ONU, indicam que o setor deverá tornar-se a principal fonte geradora de riquezas do século XXI. Estima-se, já no ano 2000, deslocamento superior a 600 milhões de pessoas.

A atividade turística é uma das mais dinâmicas do mundo. Apresenta os maiores índices de crescimento à frente de exportações de petróleo, veículos automotores e equipamentos eletrônicos. Dessa forma, é importante analisar as principais características desse investimento.

O turismo é um empreendimento excelente para economias em crescimento, apresenta renda mais democrática e é a indústria que mais cresce no mundo. Incentiva a produção de outros setores, gera milhares de empregos, aumenta as receitas das cidades, melhora a infra-estrutura local, protege e preserva o patrimônio cultural e natural. Enfim, permite o intercâmbio cultural. 


\subsection{O Trade Turístico}

O turismo envolve todo o universo de um determinado lugar. Quando se pensa em viagem, pensa-se em deslocamentos; estes deslocamentos envolvem, dependendo do lugar para onde se pretende ir, transporte aéreo, marítimo, fluvial e ferroviário. Quando se chega ao destino, o turista necessita de um meio de transporte para se locomover diariamente ou para dar continuidade ao destino, podendo servir-se de táxis, carros alugados, transporte específico para se chegar a determinados lugares como balsas, jardineiras, barcos, ferry-boat.

A rede hoteleira é a próxima rota do trade. Neste caso, são procurados para hospedagem além dos hotéis, lugares como camping, albergues, pousadas, clube de férias.

Outros estabelecimentos estão envolvidos com o trade turístico em um determinado lugar como por exemplo, restaurantes, parques temáticos e de diversões, passeios diversos em lugares como museus, feiras, dentre outros.

Para que o trade turístico funcione com eficiência, é necessário o envolvimento do governo federal e estadual, prefeituras e empresários, para que juntos realizem um trabalho eficiente e eficaz para o atendimento do turista.

\subsection{A segmentação do Turismo}

Como atividade econômica, o turismo sofre inovações constantes em face da competitividade e das exigências do fluxo turístico. Com isso, as empresas estão a caminho da especialização para oferecer produtos segmentados, destinados a uma clientela específica. Os turistas tendem cada vez mais a se dividirem por diferentes mercados, o que favorece o rápido crescimento do turismo de interesse especial. A utilização desse amplo conceito permite identificar tanto o turismo entre países como o turismo dentro do próprio país. O turismo engloba as atividades dos visitantes, incluindo os "turistas" (visitantes que pernoitam) e os "excursionistas" (visitantes por um dia).

Assim, de acordo com esses interesses, criou-se uma variedade de tipos de turismo, ordenados em segmentação, tais como:

1. Turismo de Saúde;

2. Turismo Cultural; 
3. Turismo de Eventos;

4. Turismo de Negócios;

5. Turismo de Compras;

6. Turismo Esportivo;

7. Turismo Religioso;

8. Turismo Ecológico;

9. Turismo Rural;

10. Turismo de Lazer.

Além desses, há o turismo de pesca amadora ou esportiva, de aventura, científica, gastronômico, estudantil, e cívico. O turismo pode ser também classificado de acordo com a faixa etária dos turistas: turismo jovem e turismo da melhor idade. 


\section{METODOLOGIA}

A metodologia adotada para desenvolvimento da presente monografia baseou-se em pesquisas bibliográficas e documentais sobre Diretrizes Curriculares para os cursos de Turismo oferecidos pelas faculdades do Distrito Federal. A partir de uma pesquisa de campo buscou também obter e descrever as percepções dos coordenadores a respeito do funcionamento dos cursos, especialmente quanto ao processo de formação e perfil do egresso.

O Projeto de Pesquisa teve início no mês de outubro de 2003, com os primeiros ensaios e levantamentos de dados e informações sobre o tema escolhido, quando foi possível dar consistência a problemática desenvolvida. O seu término ocorreu no mês de fevereiro de 2004, com a redação e entrega da monografia.

\subsection{O método utilizado}

O método adotado buscou orientar e dar suporte ao processo de coleta, tratamento e análise dos dados, visando ao enfoque da problemática anteriormente definida. Utilizando o critério de classificação proposto por Vergara (1998), foi possível qualificar a pesquisa de campo, em relação a dois aspectos: quanto aos fins e quanto aos meios de investigação.

Quanto aos fins, foi exploratória, descritiva e aplicada. Exploratória porque o conhecimento acumulado e sistematizado sobre diretrizes curriculares para cursos de turismo ainda se encontra muito desagregado, dissociado e repetitivo. Pode também ser considerada como descritiva, à medida que buscou obter e descrever as percepções dos coordenadores de cursos a respeito do modelo praticado. Ainda quanto aos fins, a pesquisa pode ser considerada como aplicada porque possui finalidade prática e é motivada pela necessidade de resolver problemas concretos, podendo subsidiar as próprias faculdades na organização de um modelo técnico-pedagógico mais adequado à formação profissional.

Quanto aos meios de investigação, a pesquisa foi bibliográfica, documental e de campo. Bibliográfica porque compreendeu uma revisão da literatura disponível sobre o tema, ou seja, um estudo sistematizado com base em material publicado em livros, artigos, revistas etc., em especial da legislação vigente, pertinente às 
diretrizes curriculares nacionais, visando fundamentar teoricamente o trabalho e subsidiar a análise dos dados coletados. Documental, à medida que foi necessária a obtenção dos dados a partir de documentos internos das faculdades de turismo. Ainda quanto aos meios, foi realizada uma pesquisa de campo, ou seja, uma investigação empírica junto aos coordenadores dos cursos de turismo, para a obtenção de dados sobre as suas percepções quanto ao modelo de organização curricular adotado por estes.

Considerando-se que o universo estudado era relativamente pequeno, a pesquisa documental foi realizada, de forma censitária, nas 10 (dez) faculdades que mantém cursos de turismo, localizadas no Distrito Federal, No entanto, a pesquisa empírica foi realizada com apenas 3 (três) coordenadores de cursos dessas faculdades.

\subsection{A coleta dos dados}

$\mathrm{Na}$ pesquisa bibliográfica, foi realizado um levantamento sistemático da legislação pertinente, além de livros, artigos em revistas e periódicos, anais de congressos, teses, dissertações e outras publicações, visando (i) melhor compreender as principais questões relacionadas ao tema, (ii) fundamentar teoricamente o trabalho e (iii) obter subsídios para a análise dos dados coletados nas entrevistas realizadas. No que diz respeito à pesquisa documental, esta foi realizada nos arquivos do Ministério da Educação e das faculdades envolvidas.

No primeiro momento, o contato com as Instituições aconteceu por telefone. Posteriormente, as visitas foram realizadas nas dependências das Instituições de Ensino Superior. Apesar de várias tentativas, algumas Instituições não forneceram dados documentais imprescindíveis, causando dificuldades para a realização desta pesquisa. As Instituições entrevistadas foram IESB, EuroAmericana e UniCEUB.

Algumas Instituições enviaram informações por e-mail, tendo em vista a dificuldade encontrada na compatibilidade de horários de atendimento do coordenador e os horários da visita realizada pelo pesquisador.

O questionário foi elaborado a partir de pontos fundamentais constantes nas Diretrizes Curriculares para os Cursos de Turismo, com o objetivo de enriquecer a 
coleta de dados e realizar o estudo comparativo, verificando-se se as IES estão cumprindo as Diretrizes. 


\section{ANÁLISE E APRESENTAÇÃO DOS DADOS}

A presente análise constitui-se da coleta documental de dados gerais dos cursos, ementas, planos de curso e regimentos, pesquisas na internet e entrevistas realizadas com 3 (três) coordenadores de graduação de cursos de Turismo.

$\mathrm{Na}$ apresentação dos dados e dos resultados obtidos, destacam-se os pontos principais das Diretrizes Curriculares Nacionais para os cursos de Turismo, CES/CNE 0288/2003.

Foram realizadas coletas de dados em 10 (dez) instituições do DF, apoiadas em um roteiro semi-estruturado, explorando-se todo o universo que envolve os cursos de graduação.

As entrevistas foram realizadas por amostragem em 3 (três) faculdades IESB, FTB e Euro-Americana - por meio de questões abertas que tiveram como foco temas embasados nos currículos dos cursos, na LDB e nas Diretrizes Curriculares para os cursos de graduação em Turismo.

As entrevistas tiveram um tempo médio de duração de 35 (trinta e cinco) minutos, cujas perguntas e respostas foram gravadas com a permissão prévia dos entrevistados. Foram, então, produzidas aproximadamente 120(cento e vinte) minutos de gravação, que foram devidamente transcritas no anexo A e constituem uma base empírica do presente trabalho.

Foram realizadas pesquisas na internet para obter currículos de graduação dos cursos de Turismo, bem como informações adicionais sobre os cursos, bibliotecas, quadro docente e equipamentos à disposição dos alunos para apoio instrucional. No entanto, encontram-se disponíveis nos sites somente as grades curriculares das faculdades UPIS, UniCEUB, CECAP, Euro-Americana e IESB. As grades do CNEC, Faculdades Caiçaras e FTB foram obtidas por intermédio dos coordenadores de curso de Turismo. A UNIP e o CESUBRA não permitem a disponibilização de suas grades curriculares devido orientação da Direção das faculdades que pertencem ao mesmo grupo empresarial. A grade curricular da UNIP, que foi utilizada na matriz comparativa abaixo, foi obtida por intermédio de aluno do curso de Turismo. 
O enfoque dos cursos de Turismo no DF são diversificados, o que é um ponto positivo devido à demanda diversificada do mercado.

\subsection{Matriz comparativa dos cursos de graduação em Turismo do DF}

As 10 (dez) Instituições de Ensino Superior que ministram cursos na área de Turismo do Distrito Federal são particulares.

O ingresso dos estudantes ocorre por meio de concurso vestibular e transferência de outras IES. A duração dos cursos é de 8 (oito) períodos, 4 (quatro) anos no mínimo, e no máximo 16 (dezesseis) períodos, 8 (oito) anos, em regime seriado semestral.

A carga horária de cada disciplina/matéria é de, no mínimo, 36 horas e, no máximo, 72 horas e a carga horária total dos cursos variam de 2.850 a 3.670 horas, sendo que 2.520 horas mínimas são aproveitadas com disciplinas oriundas do conteúdo básico e do conteúdo específico, acrescidas de 480 horas mínimas aproveitadas com disciplinas de conteúdo específico-profissional para a integralização curricular.

Os cursos são distribuídos em turnos matutino e noturno, com oferta de vagas anuais que variam de 100 a 300, nas instituições pesquisadas.

As grades curriculares de todos os cursos apresentam no primeiro semestre, quase que semelhantemente, as disciplinas/matérias do conteúdo básico e estudos relacionados com os aspectos sociológicos, filosóficos, históricos, metodologia cientifica, administração e língua portuguesa. Somente a FTB insere, no primeiro semestre, "língua estrangeira: o espanhol I". Muito timidamente, inserem disciplinas de conteúdos específicos, como, por exemplo, Teoria Geral do Turismo, e, ainda, estabelecem relações do turismo com a administração, teoria da informação, planejamento, economia e meio ambiente.

No segundo e terceiro semestres, ainda são ofertadas disciplinas de conhecimentos básicos, mas cresce a oferta de disciplinas do conteúdo específico, prevalecendo as disciplinas/matérias de conhecimentos específicos gerais do turismo. A língua estrangeira é oferecida em todas as IES, crescendo a oferta nos semestres seguintes. O CNEC, o IESB, o UniCEUB, o CECAP e a UPIS ofertam duas opções de língua estrangeira, ao aluno que tem a opção de 
cursar espanhol e/ou inglês que são as únicas línguas estrangeiras oferecidas pelos cursos de Turismo do DF.

A partir do quarto e quinto semestres, as ofertas de disciplinas configuram completamente suas características. Os cursos começam a tomar contornos próprios e acrescentar disciplinas/matérias específicas que caracterizam o perfil da grade curricular de cada curso, objetivando atingir o foco do curso com flexibilidade de estrutura, permitir ao aluno a diversificação de sua formação, de maneira a levá-lo a desenvolver sua capacidade de lidar com problemas e soluções, conforme comenta Profa Rose Mary6:

\begin{abstract}
"O trabalho que foi feito com a Faculdade Caiçaras foi muito bom, porque o inventário no Paranoá são eles que realizam é a área deles, tivemos uma resistência, mas perceberam que pode acontecer isso na vida profissional. De repente são convidados a fazer levantamento de uma cidadezinha e, você vai falar sobre todo o planejamento e a pessoa vai falar que você está fazendo coisa que não existe, não tem nada a ver com a realidade aqui, aprendem a ter jogo de cintura,por isso que é importante esta percepção e este contato com aluno de outras instituições, outros perfis, outras idéias está sendo muito importante."
\end{abstract}

Cada curso em sua particularidade, inicia a oferta de disciplinas com conteúdos voltados para questões ambientais, de geografia, de planejamento e gestão, de administração e empreendedorismo, de hospedagem, de agenciamento, de gastronomia, de lazer e recreação. Inicia-se também a oferta dos laboratórios. No primeiro momento, os alunos têm acesso às disciplinas básicas e teóricas; no segundo momento, passam a ter contato com as disciplinas que trazem, em seus planos de cursos e ementários, os trabalhos de cunho prático, tais como a realização de visitas e inventários, a elaboração de planos e programas, a participação em eventos turísticos, as visitas de campo em hotéis, reservas naturais, agencias de turismo e muitos outros.

A partir do sexto e sétimo semestre, iniciam-se as ofertas de Estágio Supervisionado momento em que o aluno, efetivamente, tem contato com a prática do curso. Por ser a ocasião em que este conteúdo curricular vai implementar o perfil do formando, é a fase de acompanhamento por parte dos docentes que atuam na área de estágio, acompanhando de perto e orientando o

\footnotetext{
${ }^{6}$ Entrevista da Profa Ms. Rose Mary Coordenadora do curso de Turismo da Faculdade EuroAmericana, Brasília-DF, anexo ${ }^{a}$
} 
aluno em atividades a serem desenvolvidas, e identificando as instituições onde vão atuar durante um ou dois semestres.

No oitavo e último semestre, além da oferta, de disciplinas de conhecimentos específicos, surge o projeto final de curso: a monografia de final de curso.

De acordo as Diretrizes Curriculares dos cursos de graduação em Turismo, os alunos devem apresentar trabalho de conclusão de Curso/Monografia com conteúdos opcionais, mas cumprindo normas acadêmicas relacionadas com os planos de cursos, ementários e regimentos das IES do DF. A monografia de final de curso é obrigatória, pois os coordenadores entrevistados acreditam que são indispensáveis para o desempenho profissional qualitativo do alunado.

\subsection{Grade dos cursos de graduação em Turismo do DF}

As grades curriculares dos cursos de graduação em Turismo do DF são apresentadas na matriz a seguir, possibilitando a visualização das disciplinas, classificadas por semestre, que compõem os currículos de cada uma das instituições pesquisadas. 


\begin{tabular}{|c|c|c|c|c|c|c|c|c|c|c|}
\hline Sem & IESB & UPIS & UniCEUB & CESUBRA & CECAP & CAIÇARAS & FTB & $\begin{array}{l}\text { EURO- } \\
\text { AMERICANA }\end{array}$ & UNIP & CNEC \\
\hline \multirow{8}{*}{$\begin{array}{l}1^{\circ} \\
\text { Sem }\end{array}$} & $\begin{array}{l}\text { Teoria Geral } \\
\text { Do Turismo I }\end{array}$ & $\begin{array}{l}\text { Métodos e } \\
\text { Técnicas de } \\
\text { Pesquisa em } \\
\text { Turísmo }\end{array}$ & $\begin{array}{c}\text { Língua } \\
\text { Portuguesa I }\end{array}$ & * & $\begin{array}{l}\text { Teoria Geral } \\
\text { Do Turismo I }\end{array}$ & $\begin{array}{l}\text { Introdução ao } \\
\text { Estudo do } \\
\text { turismo }\end{array}$ & \begin{tabular}{|c} 
Comunicação \\
e Expressão \\
I
\end{tabular} & Administração & Administração I & $\begin{array}{l}\text { Fundamentos do } \\
\text { Turismo e do Lazer }\end{array}$ \\
\hline & $\begin{array}{l}\text { Metodologia } \\
\text { Da Pesquisa }\end{array}$ & $\begin{array}{c}\text { Comunicação e } \\
\text { expressão I }\end{array}$ & $\begin{array}{l}\text { Introdução ao } \\
\text { Empreendimen } \\
\text { to turístico }\end{array}$ & & $\begin{array}{l}\text { Comunicação } \\
\text { E Expressão }\end{array}$ & $\begin{array}{c}\text { Cultura } \\
\text { Brasileira }\end{array}$ & Espanhol I & Filosofia & Estudos Brasileiros I & $\begin{array}{c}\text { Geografia e Espaço } \\
\text { do Turismo }\end{array}$ \\
\hline & Sociologia & $\begin{array}{l}\text { Psicologia } \\
\text { Aplicada ao } \\
\text { Turismo }\end{array}$ & $\begin{array}{c}\text { Realidade } \\
\text { Socioeconômic } \\
\text { a Brasileira }\end{array}$ & & $\begin{array}{l}\text { História da } \\
\text { Cultura }\end{array}$ & $\begin{array}{l}\text { Métodos e } \\
\text { técnicas de } \\
\text { pesquisa }\end{array}$ & $\begin{array}{l}\text { Metodologia } \\
\text { Científica } \\
\text { Aplicada }\end{array}$ & $\begin{array}{l}\text { Geografia Geral } \\
\text { e do Brasil }\end{array}$ & Geografia I & $\begin{array}{l}\text { Teoria Geral da } \\
\text { Administraçãao }\end{array}$ \\
\hline & $\begin{array}{l}\text { Filosofia Da } \\
\text { Ciência }\end{array}$ & $\begin{array}{l}\text { Introdução ao } \\
\text { Estudo do } \\
\text { Turismo }\end{array}$ & $\begin{array}{l}\text { Introdução a } \\
\text { sociologia }\end{array}$ & & $\begin{array}{c}\text { Economia Do } \\
\text { Turismo }\end{array}$ & $\begin{array}{l}\text { Teoria Geral da } \\
\text { Administração }\end{array}$ & \begin{tabular}{|} 
Introdução ao \\
Estudo do \\
Turismo
\end{tabular} & $\begin{array}{l}\text { Língua } \\
\text { Portuguesa }\end{array}$ & História I & Língua Portuguesa \\
\hline & $\begin{array}{l}\text { História Da } \\
\text { Cultura }\end{array}$ & $\begin{array}{l}\text { Teoria Geral de } \\
\text { Administração }\end{array}$ & $\begin{array}{l}\text { Iniciação a } \\
\text { ciência }\end{array}$ & & $\begin{array}{c}\text { Metodologia } \\
\text { Do Trabalho } \\
\text { Científico }\end{array}$ & Informática & $\begin{array}{c}\text { Psicologia } \\
\text { Aplicada ao } \\
\text { Turismo }\end{array}$ & $\begin{array}{c}\text { Teoria Geral do } \\
\text { Turismo I }\end{array}$ & $\begin{array}{l}\text { Metodologia } \\
\text { Científica I }\end{array}$ & $\begin{array}{l}\text { Métodos e Técnicas } \\
\text { de Pesquisa }\end{array}$ \\
\hline & $\begin{array}{l}\text { Psicologia Do } \\
\text { Trabalho E } \\
\text { Das } \\
\text { Organizações }\end{array}$ & $\begin{array}{l}\text { Tecnologia da } \\
\text { Informação } \\
\text { aplicada ao } \\
\text { Turismo }\end{array}$ & $\begin{array}{c}\text { Ética, } \\
\text { Cidadania e } \\
\text { Realidade } \\
\text { Brasileira }\left(^{(}\right)\end{array}$ & & & $\begin{array}{c}\text { Atividades } \\
\text { Complementares }\end{array}$ & $\begin{array}{l}\text { Matemática } \\
\text { Aplicada }\end{array}$ & & $\begin{array}{l}\text { Planejamento e } \\
\text { Organização do } \\
\text { Turismo I }\end{array}$ & \\
\hline & & & & & & & $\begin{array}{c}\text { Geografia do } \\
\text { Brasil }\end{array}$ & & $\begin{array}{l}\text { Sociologia I } \\
\text { (Sociologia) e } \\
\text { Sociologia II } \\
\text { (psicologia) }\end{array}$ & \\
\hline & & & & & & & & & $\begin{array}{l}\text { Trabalho de Análise } \\
\text { Interdisciplinar I - } \\
\text { Técnicas de Análise } \\
\text { de Textos }\end{array}$ & \\
\hline
\end{tabular}

- Grade curricular não fornecida pela IES 


\begin{tabular}{|c|c|c|c|c|c|c|c|c|c|c|}
\hline Sem & IESB & UPIS & UniCEUB & CESUBRA & CECAP & CAIÇARAS & FTB & $\begin{array}{c}\text { EURO- } \\
\text { AMERICANA }\end{array}$ & UNIP & CNEC \\
\hline \multirow{8}{*}{$\begin{array}{l}2^{\circ} \\
\text { Sem }\end{array}$} & Matemática & $\begin{array}{l}\text { Elementos de } \\
\text { Matemática }\end{array}$ & $\begin{array}{c}\text { Língua } \\
\text { Portuguesa II }\end{array}$ & & $\begin{array}{l}\text { Geografia } \\
\text { Geral }\end{array}$ & $\begin{array}{l}\text { Métodos } \\
\text { quantitativos }\end{array}$ & $\begin{array}{l}\text { Sociologia } \\
\text { Geral e do } \\
\text { Lazer }\end{array}$ & Economia & $\begin{array}{c}\text { Administração } \\
\text { II }\end{array}$ & $\begin{array}{c}\text { Organização e Política } \\
\text { do Turismo }\end{array}$ \\
\hline & $\begin{array}{l}\text { Teoria Geral Do } \\
\text { Turismo II }\end{array}$ & $\begin{array}{l}\text { Comunicação e } \\
\text { Expressão II }\end{array}$ & $\begin{array}{c}\text { Sistema Brasileiro } \\
\text { de Turismo e } \\
\text { Cultura Nacional }\end{array}$ & & $\begin{array}{l}\text { Teoria Geral } \\
\text { Do Turismo II }\end{array}$ & $\begin{array}{l}\text { Comunicação e } \\
\text { expressão }\end{array}$ & $\begin{array}{l}\text { Comunicação } \\
\text { e Expressão II }\end{array}$ & Historia & $\begin{array}{l}\text { Estudos } \\
\text { Brasileiros II }\end{array}$ & Economia do Turismo \\
\hline & $\begin{array}{l}\text { Administração } \\
\text { Em Empresas De } \\
\text { Turismo }\end{array}$ & $\begin{array}{l}\text { Sociologia } \\
\text { Aplicada ao } \\
\text { Turismo }\end{array}$ & História do Brasil & & $\begin{array}{l}\text { Teoria Geral } \\
\text { Da } \\
\text { Administração }\end{array}$ & $\begin{array}{l}\text { Sociologia do } \\
\text { turismo }\end{array}$ & $\begin{array}{l}\text { Teoria Geral do } \\
\text { Turismo }\end{array}$ & Informática & Geografia II & Legislação Turística \\
\hline & $\begin{array}{l}\text { Economia } \\
\text { Contemporânea }\end{array}$ & $\begin{array}{l}\text { Teoria Geral do } \\
\text { Turismo }\end{array}$ & $\begin{array}{l}\text { Tecnologia da } \\
\text { Informação } \\
\text { Aplicada ao } \\
\text { Turismo }\end{array}$ & & $\begin{array}{l}\text { Ética } \\
\text { Profissional }\end{array}$ & $\begin{array}{l}\text { Teoria Geral do } \\
\text { turismo }\end{array}$ & $\begin{array}{l}\text { Informática } \\
\text { aplicada ao } \\
\text { Turismo }\end{array}$ & $\begin{array}{l}\text { Metodologia } \\
\text { Científica }\end{array}$ & História II & $\begin{array}{l}\text { Organização e Gestão } \\
\text { dos Meios de } \\
\text { Hospedagem }\end{array}$ \\
\hline & $\begin{array}{l}\text { Comunicação } \\
\text { Verbal E Não } \\
\text { Verbal I }\end{array}$ & $\begin{array}{l}\text { Geografia } \\
\text { aplicada ao } \\
\text { turismo }\end{array}$ & $\begin{array}{l}\text { Língua Espanhola } \\
\text { I ou Língua } \\
\text { Inglesa I }\end{array}$ & & $\begin{array}{l}\text { História Do } \\
\text { Brasil }\end{array}$ & $\begin{array}{l}\text { Filosofia e } \\
\text { Ética }\end{array}$ & $\begin{array}{l}\text { Economia } \\
\text { Aplicada ao } \\
\text { Turismo }\end{array}$ & Sociologia & $\begin{array}{l}\text { Metodologia } \\
\text { Cientifica II }\end{array}$ & Inglês I \\
\hline & $\begin{array}{l}\text { Geografia } \\
\text { Aplicada Ao } \\
\text { Turismo I }\end{array}$ & $\begin{array}{l}\text { Treinamento } \\
\text { em Liderança I }\end{array}$ & $\begin{array}{c}\text { Ética, Cidadania e } \\
\text { Realidade } \\
\text { Brasileira II (*) }\end{array}$ & & $\begin{array}{l}\text { Matemática } \\
\text { Financeira }\end{array}$ & $\begin{array}{c}\text { Criatividade, } \\
\text { inovação e } \\
\text { empreendedori } \\
\text { smo }\end{array}$ & Espanhol II & $\begin{array}{l}\text { Teoria Ger. do } \\
\text { Turismo II }\end{array}$ & $\begin{array}{l}\text { Planejamento } \\
\text { e Organização } \\
\text { do Turismo }\end{array}$ & \\
\hline & & & & & & $\begin{array}{c}\text { Atividades } \\
\text { complementare } \\
\mathrm{s}\end{array}$ & $\begin{array}{l}\text { Práticas } \\
\text { Laborais I }\end{array}$ & & $\begin{array}{c}\text { Sociologia III } \\
\text { (Sociologia) e } \\
\text { Sociologia IV } \\
\text { (Psicologia) }\end{array}$ & \\
\hline & & & & & & & & & $\begin{array}{c}\text { Trabalho de } \\
\text { Analise } \\
\text { Interdisciplinar } \\
\text { II }\end{array}$ & \\
\hline
\end{tabular}




\begin{tabular}{|c|c|c|c|c|c|c|c|c|c|c|}
\hline Sem. & IESB & UPIS & UniCEUB & CESUBRA & CECAP & CAIÇARAS & FTB & \begin{tabular}{|c} 
Euro- \\
Americana
\end{tabular} & UNIP & CNEC \\
\hline \multirow{10}{*}{$3^{\circ} \mathrm{Sem}$} & $\begin{array}{l}\text { Direito Aplicado } \\
\text { Ao Turismo }\end{array}$ & $\begin{array}{l}\text { Marketing em } \\
\text { Turismo }\end{array}$ & $\underset{\text { Brasil }}{\text { Geografia do }}$ & & $\begin{array}{l}\text { Educação } \\
\text { Ambiental }\end{array}$ & $\begin{array}{c}\text { Inglês } \\
\text { Instrumental I }\end{array}$ & $\begin{array}{l}\text { Sistemas do } \\
\text { Turismo }\end{array}$ & $\begin{array}{l}\text { Antropologia } \\
\text { Cultural }\end{array}$ & $\underset{\text { Língua Espanhola }}{\text { I }}$ & $\begin{array}{l}\text { Sociologia do } \\
\text { Turismo }\end{array}$ \\
\hline & $\begin{array}{l}\text { Estatística } \\
\text { Aplicada Ao } \\
\text { Turismo }\end{array}$ & Espanhol I & $\begin{array}{c}\text { Comunicação e } \\
\text { Marketing } \\
\text { Aplicados ao } \\
\text { Turismo }\end{array}$ & & $\begin{array}{c}\text { Cultura } \\
\text { Brasileira } \\
\text { (Museologia, } \\
\text { Folclore E } \\
\text { Patrimônio } \\
\text { Histórico) }\end{array}$ & $\begin{array}{l}\text { Geografia do } \\
\text { turismo }\end{array}$ & $\begin{array}{l}\text { Geo-História } \\
\text { Aplicada ao } \\
\text { Turismo }\end{array}$ & Contabilidade & $\begin{array}{l}\text { Metodologia } \\
\text { Cientifica III }\end{array}$ & $\begin{array}{l}\text { Historia da } \\
\text { Cultura }\end{array}$ \\
\hline & $\begin{array}{l}\text { Planejamento E } \\
\text { Organização Do } \\
\text { Turismo I }\end{array}$ & $\begin{array}{l}\text { Formação } \\
\text { Cultural } \\
\text { Brasileira }\end{array}$ & $\begin{array}{c}\text { Protocolo, } \\
\text { Etiqueta, } \\
\text { Organização } \\
\text { de Cerimônias } \\
\text { e Festas }\end{array}$ & & $\begin{array}{l}\text { Informática } \\
\text { Aplicada }\end{array}$ & $\begin{array}{l}\text { Comunicação } \\
\text { e expressão }\end{array}$ & $\begin{array}{l}\text { Filosofia e Ética } \\
\text { Profissional }\end{array}$ & Estatística & $\begin{array}{l}\text { Metodologia } \\
\text { Cientifica IV }\end{array}$ & $\begin{array}{c}\text { Lazer, } \\
\text { Animação e } \\
\text { Política Cultural }\end{array}$ \\
\hline & Inglês I & $\begin{array}{l}\text { Elementos de } \\
\text { Estatística }\end{array}$ & $\begin{array}{c}\text { Política e } \\
\text { Administração } \\
\text { Aplicadas ao } \\
\text { Turismo }\end{array}$ & & $\begin{array}{l}\text { Estatística } \\
\text { Aplicada }\end{array}$ & Estatística & $\begin{array}{l}\text { Educação } \\
\text { Ambiental } \\
\text { Aplicada ao } \\
\text { Turismo }\end{array}$ & Inglês I & $\begin{array}{l}\text { Planejamento e } \\
\text { Organização do } \\
\text { Turismo III }\end{array}$ & $\begin{array}{c}\text { Org. e Gestão } \\
\text { de Ag. De } \\
\text { Viagem e } \\
\text { Turismo }\end{array}$ \\
\hline & História Do Brasil & $\begin{array}{l}\text { Organização, } \\
\text { sistemas e } \\
\text { Métodos }\end{array}$ & $\begin{array}{c}\text { Língua } \\
\text { Espanhola II ou } \\
\text { Língua Inglesa } \\
\text { II } \\
\end{array}$ & & $\begin{array}{c}\text { Meios De } \\
\text { Hospedagem }\end{array}$ & $\begin{array}{l}\text { Psicologia do } \\
\text { turismo }\end{array}$ & $\begin{array}{l}\text { Introdução ao } \\
\text { Direito }\end{array}$ & $\begin{array}{c}\text { Plan. e Orga. do } \\
\text { Turismo }\end{array}$ & $\begin{array}{l}\text { Planejamento e } \\
\text { Organização do } \\
\text { Turismo IV }\end{array}$ & $\begin{array}{l}\text { Matemática e } \\
\text { Estatística } \\
\text { Aplicada }\end{array}$ \\
\hline & $\begin{array}{l}\text { Geografia } \\
\text { Aplicada Ao } \\
\text { Turismo II }\end{array}$ & $\begin{array}{l}\text { Turismo e Meio } \\
\text { Ambiente }\end{array}$ & & & História da Arte & contabilidade & Espanhol III & Psicologia & $\begin{array}{l}\text { Planejamento e } \\
\text { Organização do } \\
\text { Turismo V }\end{array}$ & Inglês II \\
\hline & & & & & & $\begin{array}{c}\text { Laboratório de } \\
\text { pesquisa I }\end{array}$ & $\begin{array}{l}\text { Interpretação do } \\
\text { Patrimônio } \\
\text { Histórico e } \\
\text { Cultural }\end{array}$ & & $\begin{array}{l}\text { Planejamento e } \\
\text { Organização do } \\
\text { Turismo V }\end{array}$ & \\
\hline & & & & & & & $\begin{array}{c}\text { Práticas Laborais } \\
\text { II }\end{array}$ & & $\begin{array}{l}\text { Trabalho de } \\
\text { Avaliação } \\
\text { Interdisciplinar III }\end{array}$ & \\
\hline & & & & & & & & & Administração III & \\
\hline & & & & & & & & & Historia III & \\
\hline
\end{tabular}




\begin{tabular}{|c|c|c|c|c|c|c|c|c|c|c|}
\hline Sem. & IESB & UPIS & UniCEUB & CESUBRA & CECAP & CAIÇARAS & FTB & $\begin{array}{c}\text { Euro- } \\
\text { Americana }\end{array}$ & UNIP & CNEC \\
\hline \multirow{10}{*}{$4^{\circ} \mathrm{Sem}$} & $\begin{array}{c}\text { Patrimônio } \\
\text { Cultural E } \\
\text { Natural Do } \\
\text { Brasil } \\
\end{array}$ & $\begin{array}{c}\text { Patrimônio Turístico } \\
\text { Nacional e } \\
\text { Interpretação }\end{array}$ & $\begin{array}{c}\text { Planejamento e Gestão } \\
\text { de Eventos, Feiras e } \\
\text { Congressos }\end{array}$ & & $\begin{array}{c}\text { Gestão De } \\
\text { Serviços De } \\
\text { Hospedagem }\end{array}$ & $\begin{array}{c}\text { Inglês } \\
\text { Instrumental II }\end{array}$ & Estatística & Agenciamento & $\begin{array}{l}\text { Língua } \\
\text { Espanhola II }\end{array}$ & $\begin{array}{c}\text { Planejamento } \\
\text { Gerenciament } \\
\text { o Estratégico }\end{array}$ \\
\hline & $\begin{array}{l}\text { Planejamento E } \\
\text { Organização } \\
\text { Do Turismo II }\end{array}$ & Espanhol II & $\begin{array}{c}\text { Planejamento Turístico } \\
\text { e Relacionamento com } \\
\text { a Midia }\end{array}$ & & Sociologia & $\begin{array}{l}\text { Turismo e meio } \\
\text { ambiente }\end{array}$ & $\begin{array}{l}\text { Técnicas } \\
\text { Audiovisuais e } \\
\text { Fotográfica }\end{array}$ & Direito & $\begin{array}{l}\text { Metodologia } \\
\text { Cientifica V }\end{array}$ & Inglês III \\
\hline & $\begin{array}{l}\text { Sistemas De } \\
\text { Informação } \\
\text { Aplicados Ao } \\
\text { Turismo I }\end{array}$ & $\begin{array}{l}\text { Organização e } \\
\text { Gestão da } \\
\text { Recreação, Lazer e } \\
\text { entretenimento }\end{array}$ & $\begin{array}{l}\text { Tópicos Especiais em } \\
\text { Planejamento Turístico } \\
\text { (segmentação, logística }\end{array}$ & & Contabilidade & $\begin{array}{l}\text { Marketing } \\
\text { turístico }\end{array}$ & $\begin{array}{l}\text { Agro-Turismo } \\
\text { e Turismo } \\
\text { Rural }\end{array}$ & Espanhol I & $\begin{array}{l}\text { Metodologia } \\
\text { Cientifica VI }\end{array}$ & $\begin{array}{l}\text { Organização e } \\
\text { Desenvolvime } \\
\text { nto de Eventos }\end{array}$ \\
\hline & Cartografia & $\begin{array}{c}\text { Organização e } \\
\text { Gestão de } \\
\text { Empresas Turísticas }\end{array}$ & $\begin{array}{l}\text { Sociologia do Lazer } \\
\text { Aplicada ao Turismo }\end{array}$ & & $\begin{array}{c}\text { Estrutura E } \\
\text { Organização } \\
\text { De Agências } \\
\text { De Turismo } \\
\end{array}$ & $\begin{array}{l}\text { Gestão de } \\
\text { Agências de } \\
\text { Turismo }\end{array}$ & $\begin{array}{c}\text { Meios de } \\
\text { Hospedagem }\end{array}$ & Inglês II & $\begin{array}{c}\text { Planejamento e } \\
\text { Organização } \\
\text { VII }\end{array}$ & $\begin{array}{l}\text { Antropologia } \\
\text { Cultural }\end{array}$ \\
\hline & Transportes & $\begin{array}{c}\text { Administração } \\
\text { Financeira e Custos }\end{array}$ & $\begin{array}{c}\text { Língua Espanhola III ou } \\
\text { Língua Inglesa III }\end{array}$ & & $\begin{array}{l}\text { Língua } \\
\text { Inglesa I }\end{array}$ & $\begin{array}{l}\text { Organizações, } \\
\text { sistemas e } \\
\text { métodos }\end{array}$ & $\begin{array}{l}\text { Cultura } \\
\text { Brasileira }\end{array}$ & $\begin{array}{l}\text { Planejamento, } \\
\text { Organização } \\
\text { do Turismo II }\end{array}$ & $\begin{array}{l}\text { Planejamento } \\
\text { e Organização } \\
\text { do Turismo VIII }\end{array}$ & $\begin{array}{l}\text { Planejamento } \\
\text { do Lazer e da } \\
\text { Recreação }\end{array}$ \\
\hline & Inglês II & $\begin{array}{l}\text { Análise Econômica } \\
\text { do Turismo }\end{array}$ & & & $\begin{array}{l}\text { Marketing De } \\
\text { Serviços I }\end{array}$ & $\begin{array}{l}\text { Laboratório de } \\
\text { pesquisa II }\end{array}$ & $\begin{array}{c}\text { Análise de } \\
\text { Mecanismos } \\
\text { de Financ.para } \\
\text { o Turismo } \\
\end{array}$ & & $\begin{array}{l}\text { Planejamento } \\
\text { e Organização } \\
\text { do Turismo IX }\end{array}$ & \\
\hline & & & & & & & $\begin{array}{c}\text { Direito } \\
\text { Ambiental }\end{array}$ & & $\begin{array}{l}\text { Planejamento } \\
\text { e Organização } \\
\text { do Turismo X }\end{array}$ & \\
\hline & & & & & & & $\begin{array}{l}\text { Práticas } \\
\text { Laborais III }\end{array}$ & & $\begin{array}{c}\text { Trabalho de } \\
\text { Analise } \\
\text { Interdisciplinar } \\
\text { IV } \\
\end{array}$ & \\
\hline & & & & & & & & & $\begin{array}{l}\text { Administração } \\
\text { IV }\end{array}$ & \\
\hline & & & & & & & & & Historia IV & \\
\hline
\end{tabular}




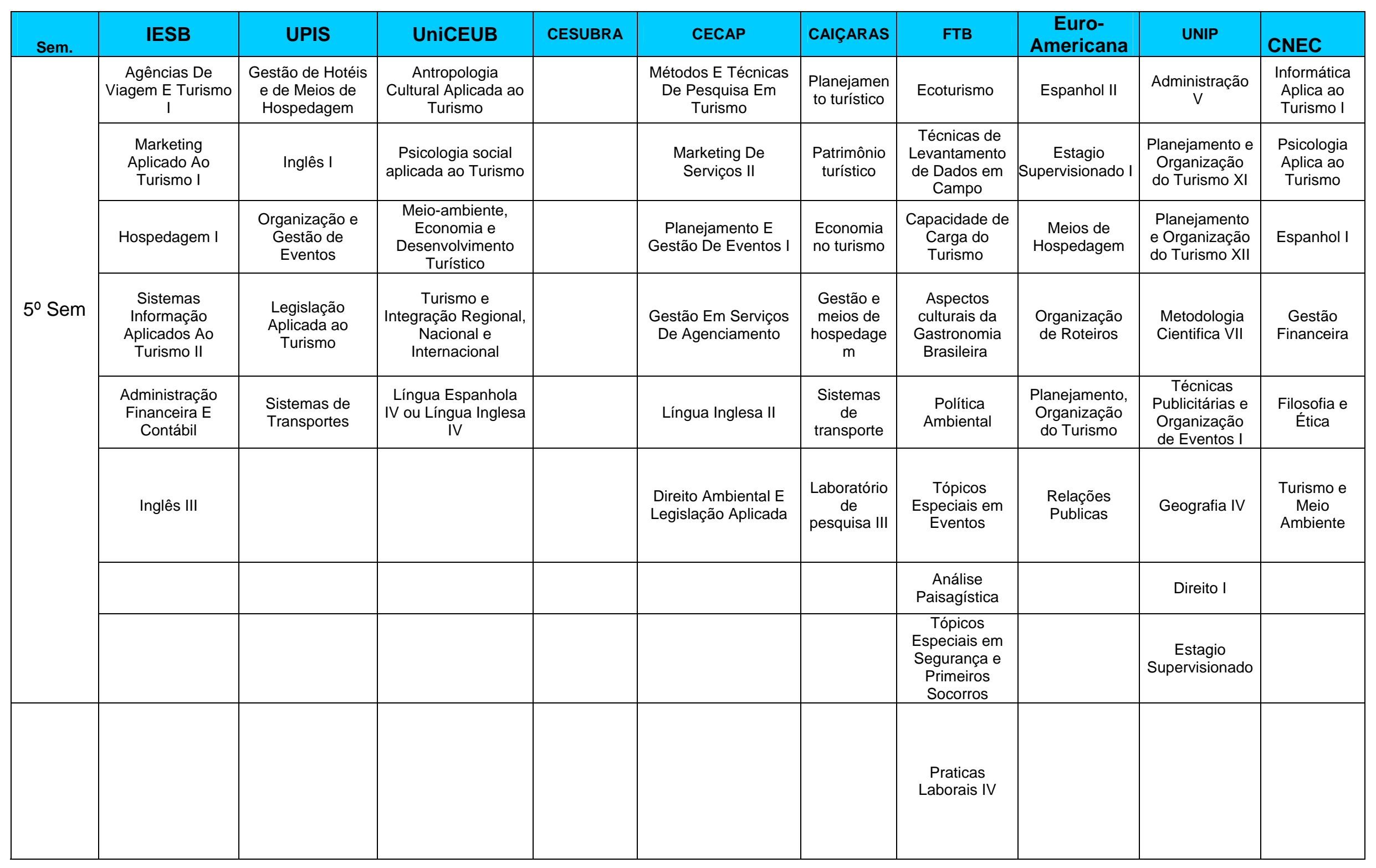




\begin{tabular}{|c|c|c|c|c|c|c|c|c|c|c|}
\hline Sem. & IESB & UPIS & UniCEUB & $\begin{array}{c}\text { CESUBR } \\
\text { A }\end{array}$ & CECAP & CAIÇARAS & FTB & \begin{tabular}{|l} 
Euro- \\
Americana
\end{tabular} & UNIP & CNEC \\
\hline \multirow{7}{*}{$\begin{array}{c}6^{\circ} \\
\text { Sem }\end{array}$} & $\begin{array}{l}\text { Laboratório De } \\
\text { Turismo }\end{array}$ & $\begin{array}{l}\text { Tópico Especial } \\
\text { (Ecoturismo) }\end{array}$ & $\begin{array}{c}\text { Marketing Pessoal e } \\
\text { Relaç̃es } \\
\text { Interpessoais } \\
\text { Aplicadas ao } \\
\text { Turismo } \\
\end{array}$ & & $\begin{array}{l}\text { Gestão De } \\
\text { Serviços De } \\
\text { Alimentação }\end{array}$ & $\begin{array}{c}\text { Associativism } \\
\text { o e } \\
\text { desenvolvime } \\
\text { nto } \\
\text { participativo I } \\
\end{array}$ & $\begin{array}{l}\text { Planejamento e } \\
\text { Organização do } \\
\text { Turismo }\end{array}$ & $\begin{array}{l}\text { Ecologia e } \\
\text { Legislação } \\
\text { Ambiental }\end{array}$ & $\begin{array}{c}\text { Administração } \\
\text { VI }\end{array}$ & $\begin{array}{l}\text { Informática } \\
\text { Aplicada ao } \\
\text { Turismo II }\end{array}$ \\
\hline & $\begin{array}{l}\text { Administração De } \\
\text { Recursos Humanos }\end{array}$ & $\begin{array}{l}\text { Tópico Especial } \\
\text { (Relações } \\
\text { Internacionais }\end{array}$ & $\begin{array}{c}\text { Gestão Financeira, } \\
\text { Contábil e } \\
\text { Estatística aplicadas } \\
\text { ao turismo }\end{array}$ & & Antropologia & $\begin{array}{l}\text { Legislação } \\
\text { turística }\end{array}$ & $\begin{array}{l}\text { Ecossistemas e } \\
\text { Unidades de } \\
\text { Conservação }\end{array}$ & $\begin{array}{c}\text { Estagio } \\
\text { Supervisionado II }\end{array}$ & \begin{tabular}{|} 
Planejamento \\
e Organização \\
do Turismo XIII
\end{tabular} & $\begin{array}{l}\text { Marketing de } \\
\text { Serviços }\end{array}$ \\
\hline & $\begin{array}{l}\text { Marketing Aplicado } \\
\text { Turismo II }\end{array}$ & $\begin{array}{l}\text { Tópico Especial } \\
\text { (Turismo Virtual) }\end{array}$ & $\begin{array}{c}\text { Direito, Ética e } \\
\text { Legislação } \\
\text { Aplicados ao } \\
\text { Turismo } \\
\end{array}$ & & $\begin{array}{l}\text { Planejamento E } \\
\text { Gestão De } \\
\text { Eventos II }\end{array}$ & $\begin{array}{c}\text { Planejamento } \\
\text { e } \\
\text { desenvolvime } \\
\text { nto } \\
\text { Participativo I } \\
\end{array}$ & Contabilidade & $\begin{array}{l}\text { Organização de } \\
\text { Eventos }\end{array}$ & $\begin{array}{c}\text { Metodologia } \\
\text { Cientifica VIII }\end{array}$ & $\begin{array}{l}\text { Gestão de } \\
\text { Qualidade em } \\
\text { Eventos }\end{array}$ \\
\hline & Hospedagem II & $\begin{array}{c}\text { Tópico Especial } \\
\text { (Gestão de } \\
\text { serviços) }\end{array}$ & $\begin{array}{l}\text { Língua EspanholaV } \\
\text { ou Língua Inglesa V }\end{array}$ & & $\begin{array}{l}\text { Turismo e Meio } \\
\text { Ambiente }\end{array}$ & \begin{tabular}{|c|} 
Lazer \\
recreação e \\
entreteniment \\
0 \\
\end{tabular} & $\begin{array}{l}\text { Elaboração de } \\
\text { Roteiro } \\
\text { Ecoturístico } \\
\end{array}$ & Restaurante & \begin{tabular}{|c|} 
Técnicas \\
Publicitarias e \\
Organização \\
de Eventos II \\
\end{tabular} & $\begin{array}{l}\text { Gestão de } \\
\text { Recursos } \\
\text { Humanos } \\
\end{array}$ \\
\hline & & & & & & & & & Geografia VI & $\begin{array}{c}\text { Estagio } \\
\text { Supervisionadd } \\
\text { de Turismo I }\end{array}$ \\
\hline & & & & & & & & & Direito II & \\
\hline & & & & & & & & & $\begin{array}{c}\text { Estagio } \\
\text { Supervisionado }\end{array}$ & \\
\hline
\end{tabular}




\begin{tabular}{|c|c|c|c|c|c|c|c|c|c|c|}
\hline Sem. & IESB & UPIS & UniCEUB & CESUBRA & CECAP & $\begin{array}{l}\text { CAIÇARA } \\
\text { S }\end{array}$ & FTB & $\begin{array}{c}\text { EURO- } \\
\text { AMERICANA }\end{array}$ & UNIP & CNEC \\
\hline \multirow{10}{*}{$\begin{array}{c}7^{0} \\
\text { Sem }\end{array}$} & $\begin{array}{l}\text { Organização de } \\
\text { Eventos }\end{array}$ & Inglês II & $\begin{array}{l}\text { Patrimônio Histórico } \\
\text { e Cultural Nacionais }\end{array}$ & & $\begin{array}{c}\text { Dimensões Do } \\
\text { Lazer }\end{array}$ & $\begin{array}{l}\text { Ecoturismo e } \\
\text { turismo rural }\end{array}$ & $\begin{array}{l}\text { Formação do } \\
\text { Empreendedor }\end{array}$ & $\begin{array}{l}\text { Alimentos e } \\
\text { Bebidas }\end{array}$ & $\begin{array}{c}\text { Administração } \\
\text { VII }\end{array}$ & $\begin{array}{l}\text { Seminário } \\
\text { Integrador }\end{array}$ \\
\hline & $\begin{array}{l}\text { Técnicas De } \\
\text { Animação }\end{array}$ & $\begin{array}{l}\text { Gestão de } \\
\text { Pessoas }\end{array}$ & $\begin{array}{c}\text { Informática, } \\
\text { Economia digital e } \\
\text { turismo }\end{array}$ & & $\begin{array}{c}\text { Planejamento } \\
\text { E Organização } \\
\text { Do Turismo }\end{array}$ & $\begin{array}{l}\text { Estudo do } \\
\text { potencial } \\
\text { turístico } \\
\text { brasileiro } \\
\end{array}$ & $\begin{array}{l}\text { Meios de } \\
\text { Transportes }\end{array}$ & $\begin{array}{c}\text { Estagio } \\
\text { Supervisionado III }\end{array}$ & $\begin{array}{c}\text { Administração } \\
\text { VIII }\end{array}$ & Espanhol III \\
\hline & $\begin{array}{l}\text { Laboratório De } \\
\text { Hotelaria }\end{array}$ & $\begin{array}{l}\text { Planejamento e } \\
\text { Organização } \\
\text { do Turismo I }\end{array}$ & $\begin{array}{l}\text { Marketink social, de } \\
\text { serviços e } \\
\text { Institucional } \\
\text { aplicados ao turismo }\end{array}$ & & $\begin{array}{l}\text { Qualidade Em } \\
\text { Serviços } \\
\text { Turísticos }\end{array}$ & $\begin{array}{c}\text { Planejament } \\
\text { o e } \\
\text { desenvolvim } \\
\text { ento } \\
\text { participativo } \\
\text { II } \\
\end{array}$ & $\begin{array}{c}\text { Gestão } \\
\text { Administrativa }\end{array}$ & $\begin{array}{c}\text { Gestão de } \\
\text { Empresas Turísticas }\end{array}$ & $\begin{array}{l}\text { Metodologia } \\
\text { Cientifica IX }\end{array}$ & $\begin{array}{l}\text { Eventos: } \\
\text { Espaços } \\
\text { Alternativos }\end{array}$ \\
\hline & Espanhol I & $\begin{array}{c}\text { Ética } \\
\text { profissional de } \\
\text { Turismo }\end{array}$ & $\begin{array}{c}\text { Empreendimento } \\
\text { Turístico e Empresa } \\
\text { Jr II }\end{array}$ & & $\begin{array}{l}\text { Meios De } \\
\text { Transporte E } \\
\text { Gestão De } \\
\text { Serviços De } \\
\text { Transportes } \\
\end{array}$ & $\begin{array}{l}\text { Gestão de } \\
\text { recursos } \\
\text { humanos }\end{array}$ & $\begin{array}{c}\text { Agência de } \\
\text { Viagem e Turismo }\end{array}$ & $\begin{array}{c}\text { Legislação e } \\
\text { Projetos Turísticos }\end{array}$ & Língua Inglesa & $\begin{array}{c}\text { Disciplina } \\
\text { Complementar } \\
\text { I }\end{array}$ \\
\hline & $\begin{array}{l}\text { Alimentos E } \\
\text { Bebidas }\end{array}$ & $\begin{array}{l}\text { Treinamento } \\
\text { em Liderança II }\end{array}$ & $\begin{array}{c}\text { Língua Espanhola } \\
\text { VI ou Língua Inglesa } \\
\text { VI }\end{array}$ & & $\begin{array}{c}\text { Elaboração E } \\
\text { Gerenciamento } \\
\text { De Projetos } \\
\text { Turísticos I }\end{array}$ & $\begin{array}{l}\text { Organização } \\
\text { e Gestão de } \\
\text { eventos }\end{array}$ & Espeleoturismo & $\begin{array}{c}\text { Marketing II } \\
\text { (Marketing Turístico) }\end{array}$ & $\begin{array}{l}\text { Gestão em } \\
\text { Agencia I }\end{array}$ & $\begin{array}{l}\text { Historia das } \\
\text { Civilizações }\end{array}$ \\
\hline & $\begin{array}{c}\text { Estágio } \\
\text { Supervisionado } \\
\text { Em Turismo II } \\
\end{array}$ & Estágio I & & & $\begin{array}{l}\text { Formação Do } \\
\text { Empreendedor }\end{array}$ & $\begin{array}{c}\text { Estágio } \\
\text { supervisiona } \\
\text { do I } \\
\end{array}$ & $\begin{array}{c}\text { Estágio } \\
\text { Supervisionado }\end{array}$ & $\begin{array}{l}\text { Parques Temáticos } \\
\text { e Aquáticos }\end{array}$ & $\begin{array}{l}\text { Gestão em } \\
\text { Agencia II }\end{array}$ & $\begin{array}{c}\text { Estagio } \\
\text { Supervisionado } \\
\text { em Turismo II }\end{array}$ \\
\hline & & & & & $\begin{array}{c}\text { Psicologia } \\
\text { Aplicada E } \\
\text { Administração } \\
\text { De Pessoas }\end{array}$ & & & & $\begin{array}{c}\text { Elaboração de } \\
\text { Roteiros I }\end{array}$ & \\
\hline & & & & & $\begin{array}{c}\text { Estagio } \\
\text { Supervisionado } \\
\text { I }\end{array}$ & & & & $\begin{array}{l}\text { Procedimentos } \\
\text { Operacionais } \\
\text { em Agencia I }\end{array}$ & \\
\hline & & & & & & & & & $\begin{array}{l}\text { Procedimentos } \\
\text { Operacionais } \\
\text { em Agencia II }\end{array}$ & \\
\hline & & & & & & & & & $\begin{array}{c}\text { Estagio } \\
\text { Supervisionado }\end{array}$ & \\
\hline
\end{tabular}




\begin{tabular}{|c|c|c|c|c|c|c|c|c|c|c|}
\hline Sem. & IESB & UPIS & UniCEUB & CESUBRA & CECAP & $\begin{array}{c}\text { CAIÇARA } \\
\mathrm{S}\end{array}$ & FTB & $\begin{array}{c}\text { Euro- } \\
\text { Americana }\end{array}$ & UNIP & CNEC \\
\hline \multirow{10}{*}{$\begin{array}{l}8^{\circ} \\
\text { Sem }\end{array}$} & $\begin{array}{c}\text { Tópicos Especiais } \\
\text { Em Turismo }\end{array}$ & $\begin{array}{c}\text { Destinos e fluxos } \\
\text { turísticos } \\
\text { mundiais }\end{array}$ & $\begin{array}{c}\text { Estágio } \\
\text { Supervisionado }\end{array}$ & & $\begin{array}{l}\text { Administração } \\
\text { Financeira }\end{array}$ & $\begin{array}{c}\text { Política de } \\
\text { desenvolvim } \\
\text { ento local e } \\
\text { regional }\end{array}$ & $\begin{array}{c}\text { Relações } \\
\text { Humanas nas } \\
\text { Organizações }\end{array}$ & Cerimonial & Administração IX & $\begin{array}{c}\text { Tendências de } \\
\text { Merc. E } \\
\text { Competitividade } \\
\text { Formação do } \\
\text { Empreendedor }\end{array}$ \\
\hline & $\begin{array}{c}\text { Higiene E } \\
\text { Segurança Do } \\
\text { Trabalho }\end{array}$ & $\begin{array}{c}\text { turismo nas } \\
\text { regiões brasileiras }\end{array}$ & $\begin{array}{l}\text { Projeto Final } \\
\text { (monografia) }\end{array}$ & & $\begin{array}{c}\text { Gestão De } \\
\text { Serviços De } \\
\text { Lazer E } \\
\text { Entretenimento }\end{array}$ & $\begin{array}{l}\text { Estudos de } \\
\text { viabilidade }\end{array}$ & $\begin{array}{c}\text { Visão } \\
\text { Mercadológica } \\
\text { (Marketing } \\
\text { Turístico) } \\
\end{array}$ & $\begin{array}{c}\text { Ecoturismo e } \\
\text { Planejamento } \\
\text { Ambiental }\end{array}$ & Administração X & $\begin{array}{l}\text { Estratégias de } \\
\text { Com. E } \\
\text { Relacionamento }\end{array}$ \\
\hline & $\begin{array}{l}\text { Comunicação } \\
\text { Verbal E Não } \\
\text { Verbal II }\end{array}$ & $\begin{array}{c}\text { Planejamento e } \\
\text { Organização do } \\
\text { Turismo II }\end{array}$ & $\begin{array}{c}\text { Atividades } \\
\text { Complementares }\end{array}$ & & $\begin{array}{c}\text { Elaboração E } \\
\text { Gerenciamento } \\
\text { De Projetos } \\
\text { Turísticos II }\end{array}$ & \begin{tabular}{|c|} 
Implantação \\
e \\
gerenciamen \\
to de \\
projetos \\
\end{tabular} & $\begin{array}{c}\text { Inglês } \\
\text { Instrumental }\end{array}$ & $\begin{array}{c}\text { Estagio } \\
\text { Supervisionado } \\
\text { IV }\end{array}$ & $\begin{array}{l}\text { Metodologia } \\
\text { Cientifica X }\end{array}$ & $\begin{array}{c}\text { Disciplina } \\
\text { Complementar II }\end{array}$ \\
\hline & Gestão Ambiental & $\begin{array}{c}\text { Composto } \\
\text { Promocional em } \\
\text { Turismo }\end{array}$ & & & $\begin{array}{c}\text { Publicidade E } \\
\text { Relações } \\
\text { Públicas } \\
\text { Aplicadas } \\
\end{array}$ & $\begin{array}{c}\text { Gestão da } \\
\text { informação } \\
\text { eletrônica } \\
\text { em turismo } \\
\end{array}$ & $\begin{array}{l}\text { Análise de } \\
\text { Projetos }\end{array}$ & $\begin{array}{l}\text { Gest. Financ. } \\
\text { Estud. Viabil. }\end{array}$ & Língua Inglesa II & $\begin{array}{l}\text { Planejamento e } \\
\text { Org. do Turismo }\end{array}$ \\
\hline & Espanhol II & Estágio II & & & $\begin{array}{l}\text { Técnicas De } \\
\text { Animação E } \\
\text { Recreação }\end{array}$ & $\begin{array}{l}\text { Promoção e } \\
\text { qualidade do } \\
\text { produto } \\
\text { turístico } \\
\end{array}$ & $\begin{array}{c}\text { Estágio } \\
\text { Supervisionado II }\end{array}$ & $\begin{array}{l}\text { Técnicas de } \\
\text { Recreação }\end{array}$ & $\begin{array}{l}\text { Gestão em } \\
\text { Agência III }\end{array}$ & $\begin{array}{c}\text { Implementação } \\
\text { de Projetos } \\
\text { Turisticos }\end{array}$ \\
\hline & $\begin{array}{c}\text { Elaboração De } \\
\text { Projetos } \\
\text { Turísticos } \\
\end{array}$ & & & & $\begin{array}{c}\text { Estágio } \\
\text { Supervisionado II }\end{array}$ & \begin{tabular}{|c|} 
Estágio \\
supervisiona \\
do II \\
\end{tabular} & & $\begin{array}{l}\text { Técnicas } \\
\text { Publicas }\end{array}$ & $\begin{array}{l}\text { Gestão em } \\
\text { Agencia IV }\end{array}$ & $\begin{array}{c}\text { Estagio } \\
\text { Supervisionado } \\
\text { de Turismo III }\end{array}$ \\
\hline & $\begin{array}{c}\text { Estágio } \\
\text { Supervisionado III }\end{array}$ & & & & & & & & $\begin{array}{l}\text { Elaboração de } \\
\text { Roteiros II }\end{array}$ & \\
\hline & & & & & & & & & $\begin{array}{c}\text { Procedimentos } \\
\text { operacionais em } \\
\text { Agencia III }\end{array}$ & \\
\hline & & & & & & & & & $\begin{array}{c}\text { Procedimentos } \\
\text { Operacionais em } \\
\text { Agencia IV } \\
\end{array}$ & \\
\hline & & & & & & & & & $\begin{array}{c}\text { Estagio } \\
\text { Supervisionado }\end{array}$ & \\
\hline $\begin{array}{l}\mathrm{N}^{\mathrm{O}} \text { de } \\
\text { Horas } \\
\text { Aula }\end{array}$ & 3.144 & 2.850 & & & 3.036 & 3.670 & 3.000 & 2.880 & 3.200 & 3.240 \\
\hline
\end{tabular}




\section{DESCRIÇÃO DOS DADOS APRESENTADOS}

As entrevistas com os coordenadores dos cursos de Turismo seguiram um roteiro de perguntas elaboradas pelo pesquisador, por amostragem, com o intuito de verificar se as Instituições de Ensino Superior do Distrito Federal estão cumprindo as Diretrizes Curriculares dos cursos de graduação em Turismo na organização e estruturação de seus currículos.

As perguntas elaboradas foram as seguintes:

1) Quais são os objetivos gerais do curso de Turismo na Instituição coordenada pelo (a) Senhor(a)?

2) Como a Instituição promove a interação entre a teoria e a prática?

3) Como é feita a avaliação dos alunos?

4) Qual percentual de evasão no curso de Turismo na Instituição?

De acordo com as Diretrizes Curriculares Nacionais, os cursos de graduação em Turismo devem refletir uma dinâmica que atenda aos diferentes perfis de desempenho profissional. A sociedade em suanessa heterogeneidade de mudanças sociais, sempre acompanhadas de novas e mais sofisticadas tecnologias, exige, contínuas revisões do Projeto Pedagógico de um curso para que ele se constitua numa caixa de ressonância dessas demandas, formando um profissional crítico e de suficiente autonomia intelectual, com conhecimento que se ajuste sempre às necessidades emergentes, notadamente na expansão do turismo em suas múltiplas modalidades no Brasil e no Mundo.

Como se pode notar nos depoimentos adiante transcritos, esta preocupação tem sido constante entre os coordenadores dos cursos de Turismo:

\footnotetext{
"Nosso objetivo é oferecer a esse aluno esses domínios, estes conhecimentos, aí, para que ele se torne um cidadão melhor, com uma responsabilidade social, com visão global da realidade do mundo onde ele está inserido e que ele seja um retorno do desenvolvimento responsável e sustentável do turismo no Brasil" (Profa. Dra. Cláudia Brochado - IESB).

"Nossa idéia é que o curso dê uma visão geral que todas as áreas possíveis de atuação, para que o aluno tenha essa percepção de escolha da área que quer atuar e dessa necessidade de continuar atualizando-se, só que seu eu não formar um profissional com essa visão ele não consegue depois, na hora que ele termina, ele fala e agora, então a idéia é que ele seja agente dessa própria educação da construção do seu próprio conhecimento" (Profa. Ms. Rose Mary Euro-Americana).

"Formar profissional competente em Turismo, com as capacidades técnicas e éticas necessárias. Formar um cidadão, no sentido pleno de um indivíduo participante de uma sociedade e solidário com seus membros, com consciência da complexidade do mundo atual. Preparar empreendedores capaz de atuar em uma sociedade globalizada, que seja capaz de
} 
fazer frente às exigências de mercado dentro ou fora do Brasil".(Prof. Mauro de Castro, UniCEUB).

Os coordenadores entrevistados foram indagados também sobre os objetivos gerais dos cursos de Turismo da Instituição, em que trabalham, cuja exigência está clara nas Diretrizes Curriculares, em seu art. $1^{\circ}$, parágrafo $1^{\circ}$ :

\begin{abstract}
o projeto pedagógico do curso, além da clara concepção do curso de graduação em turismo, com suas peculiaridades, seu currículo pleno e sua operacionalização, abrangerá, sem prejuízo de outros, os seguintes elementos estruturais: objetivos gerais do curso, contextualizados em relação a suas inserções institucional, política, geográfica e social.
\end{abstract}

As respostas foram apresentadas de forma clara e consistente, como descritas abaixo, evidenciando a preocupação em atender à demanda do mercado:

\begin{abstract}
Em primeiro lugar, a gente entende que por ser um curso de nível superior, o aluno precisa, antes de mais nada, ter uma visão ampla da sociedade, crescer enquanto cidadão, ter responsabilidade social, nesse sentido a gente oferece aquelas matérias do tronco comum de um curso da área de humanas que são as matérias básicas que vão ajudar justamente na formação do indivíduo que chega a ter um nível superior: filosofia, história, sociologia, economia e assim por diante, por outro lado a gente -sabe também que é importante para este aluno dominar as ferramentas necessárias para atuar no mercado trabalho, chamadas habilidades e competências que tem sido hoje em dia questionadas dentro das diretrizes curriculares do MEC.(Profa Dra. Cláudia Brochado, IESB).
\end{abstract}

O objetivo geral é a idéia de formar um profissional justamente como eu comentei com você a história do foco, o nosso foco é formar pessoas para planejamento e gestão de todas as atividades do turismo, porque nós sentimos justamente em discussão com os profissionais da área, os turismólogos, quais são as necessidades, o que o mercado está pedindo, a idéia é o que o governo está solicitando, o que a academia está precisando, então essa idéia de voltarmos somente a um tipo de mercado é muito volátil, você está formando um profissional que daqui 4 anos, quando ele sair da faculdade ele está obsoleto, então a idéia é justamente ter uma formação profissional de "pensadores" (Profa Ms. Rose Mary - Euro-Americana).

Formar profissional competente em Turismo, com as capacidades técnicas e éticas necessárias. Formar um cidadão, no sentido pleno de um indivíduo participante de uma sociedade e solidário com seus membros, com consciência da complexidade do mundo atual. (Prof. Mauro de Castro, coordenador do curso de turismo no UniCEUB).

A forma de interação entre teoria e prática é um aspecto relevante nas Diretrizes Curriculares. De acordo o parágrafo $1^{\circ}$, inciso $\mathrm{V}$, do artigo $2^{\circ}$, esta interação compreende visitas técnicas, inventário turístico, laboratórios de aprendizagem e de estágios, assim sendo, a próxima pergunta refere-se a este item. Os coordenadores entrevistados falaram dos projetos, em que estão inseridos os seus cursos, dos eventos que promovem em suas instituições e da forma como vêem este assunto:

a gente incentiva também algumas atividades práticas para que o aluno possa trabalhar efetivamente com conteúdos, é o caso das matérias de planejamento que nós já fizemos, por 
exemplo, aqui um projeto que foi de parceria com 2 (duas) cidades: Paracatu e Niquelândia, fizemos inventário turístico da cidade, então isso é um trabalho prático que é algo até comum nos cursos de turismo estas atividades que são inventários de municípios. Outras coisas são saídas que eles fazem, para verificar as condições de um empreendimento com relação aos aspectos de sustentabilidade social, ambiental e etc. Quando eles vão fazer uma visita ao empreendimento, eles vão estar observando isso e fazendo relatório, observa se existe preocupação naquele estabelecimento com a questão ambiental, com o tratamento seletivo da questão do plano de manejo na utilização dos espaços, e etc. Então esta também é uma atividade que eles vão estar fazendo na prática. Depois nós temos também atividades relacionadas com a semana de turismo e hotelaria que muitas vezes eles trazem grupos para estarem aqui apresentando seus trabalhos, tanto de empreendimento quanto de grupos artísticos com manifestações culturais. Temos uma atividade aqui que é constante que é o "Café com artes" que faz parte da disciplina "Organização de eventos" que acontece todas as terças-feiras, eles organizam o evento aqui que acontece justamente neste espaço que você está vendo. O palco foi montado porque os eventos acontecem aqui na cantina e então os alunos já trouxeram de tudo aqui, muitos eventos relacionados a música e muitas outras coisas, então é uma outra atividade prática, ela é constante dentro de uma disciplina específica (Prof ${ }^{\mathrm{D}}$ Dra. Cláudia Brochado. IESB).

A idéia é mostrar para os alunos como é que funciona realmente essa integração da teoria com a prática, a partir do trabalho semestral interdisciplinar que a gente chama de TSI, o que acontece, são dados temas e todas as turmas em grupos, a idéia de trabalhar em equipe que é interdisciplinar e os alunos tem nesse trabalho que fazer a ligação de todas as disciplinas, então eles vão pra campo mesmo, vão fazer entrevista, vão ver como é que é a vida real e pra realmente vivenciar na prática, depois eles têm que ter um relatório para apresentar para as bancas e, nesse relatório tem que apresentar como que eles viam isso na teoria e como que são as visitas técnicas, cada turma tem suas visitas técnicas que são sempre acompanhadas pelos professores. Nessas visitas, os alunos têm oportunidade de ver como que é feito, então tem toda uma parte realmente de inventariado de diagnóstico, então isso para nós é extremamente importante porque eu não posso falar de planejamento se eu não fiz um inventário, se eu não fui lá e reconheci como é o local, seu eu não fiz um diagnóstico de quais são os problemas, e como que a gente vai fazer para solucioná-los.

Realizamos uma visita técnica em grupo no Bay Park, ao final apresentaram diagnóstico e sugestões. O pessoal do Bay Park ficou tão impressionado com o trabalho de uma das alunas e convidou-a para estagiar lá e o trabalho de conclusão de curso vai ser realizado lá, justamente fazendo planejamento toal da reformulação do Bay Park. A integração acontece e a comunidade começa a receber isso de volta que é uma das funções da universidade. (Profa Rose Mary , Euro-Americana).

Em virtude da importância para a realização deste trabalho, da identificação do perfil do formando, a pergunta de número 3 foi formulada com o intuito de verificar qual a forma de avaliação utilizada pelas Instituições entrevistadas, em vista do que o Art. 10 das Diretrizes Curriculares para os Cursos de Turismo prevê: “(...) as instituições deverão adotar formas específicas e alternativas de avaliação, internas e externas (...), observados os aspectos fundamentais para a identificação do perfil do formando.

Há uma percepção uniforme dos entrevistados quanto a importância desta questão, pois apresentaram prontamente as formas de avaliação adotadas pelas IES:

É uma das exigências também é que o professor não dê só um tipo de avaliação, a gente acredita que a prova escrita é um instrumento importante porque é uma avaliação individual e outros também, como por exemplo os trabalhos em grupo, porque a gente sabe que é muito importante hoje em dia para o aluno desenvolver a capacidade de trabalhar em equipe, a gente 
sabe que qualquer profissional hoje em dia para ter sucesso ele tem que trabalhar em equipe, tem que saber dividir, ele tem que saber se satisfazer também com as vitórias dos outros, não só com as deles. Este é o profissional hoje em dia que se espera formar, não é aquele individualista que trabalha e quer todos os méritos para si, e não tenha a capacidade de dividir e trabalhar em equipe tem que saber dividir, ele tem que saber satisfazer também com as vitórias dos outros, não só com as deles. (Profa Cláudia Brochado, IESB, Anexo A, 2003).

A avaliação é feita com os trabalhos interdisciplinares, tem acompanhamento de uma banca durante todos os trabalhos, momentos de orientação, isso já faz parte do processo de avaliação, acompanhamento dos grupos, conversando com os alunos, tem o retorno imediato, identificando as dificuldades pra poder estar recuperando e vivenciando o interesse, além das provas formais que fazem parte do regimento da faculdade, os relatórios são contados como nota, e isso é feito a cada início de semestre, os professores passam pro aluno e ele já sabe do processos (Prof ${ }^{\mathrm{R}}$ Rose Mary, Euro-Americana).

O Prof. Mauro de Castro, do UniCEUB, limitou-se a responder que "são cobradas duas avaliações no semestre", não explicitando de que forma as avaliações são feitas e se ocorrem de forma alternativa.

Os coordenadores do IESB e da Euro-americana falaram também que, de acordo com o regimento interno, no primeiro dia de aula os professores entram em sala com o plano de curso e já definem como trabalharão a metodologia e as avaliações que irão adotar durante o semestre para cada disciplina. Cabe ressaltar que é um fator altamente positivo as instituições adotarem formas de avaliação diversas da convencional, uma vez que, além das IES estarem cumprindo as Diretrizes, os alunos podem realizar trabalhos em equipe e demonstrarem seu potencial nas disciplinas práticas que as faculdades adotam para diversificar o universo acadêmico, enriquecendo o conhecimento de seus educandos.

$\mathrm{Na}$ finalização da enquete, os coordenadores foram indagados pelo pesquisador sobre a questão da evasão nos cursos de Turismo. Foi formulada, devido a sua relevância na avaliação se o curso está atendendo às expectativas da clientela.

As respostas dos coordenadores foram as seguintes:

Eu não saberia dizer esse percentual, eu só sei que na nossa $1^{\mathrm{a}}$ turma de formandos que aconteceu no mês de julho, formaram um número muito significativo de alunos, eu acho que não tínhamos nem 100 (cem) alunos no início do curso e a nossa $1^{a}$ turma tinha 60 alunos, então é um percentual muito grande de formandos, quer dizer também que o aluno não abandonou, às vezes o aluno reprovou em uma matéria, trancou o semestre e depois retornou e perdeu a turma. Além de ter uma baixa evasão o IESB recebe uma quantidade muito grande de pedidos de transferência, então todo semestre é uma quantidade muito grande de alunos que vem de fora, filhos de pessoas que são da área de turismo que vem pra Brasília, como filho de presidente de companhia aérea, filho de um dono de um grande hotel, muitos escolhem o IESB pra estudar, além dos pedidos de outras faculdades do DF. (Profa Dra.Cláudia Brochado, IESB).

Durante um tempo, no começo do curso, houve uma evasão muito grande, eu não estava aqui na época, mas acredito que foi devido à falta de estrutura, era um curso novo no mercado, a partir do momento em que criamos este laboratório, a vinda da Prof. Janice pra cá, a 
implementação da interdisciplinaridade melhoru muito. Mas a evasão é normal, acredito que $10 \%$ no máximo, e inclusive a gente está recebendo alunos de outras faculdades, a evasão é muito maior pela questão econômica, as pessoas não estão podendo pagar, trancam porque não estão dando conta de pagar e não por causa do curso, e às vezes tranca e volta a cursar novamente, (Profa Rose Mary, Auro-Americana).

A questão da evasão, de acordo com a fala das coordenadoras do IESB e da EuroAmericana, tem aspecto financeiro e não de qualidade dos cursos, ou de não-atendimento das expectativas dos alunos.

O Prof. Mauro Rabelo coordenador do curso de Turismo do UniCEUB, respondeu apenas que se trata de uma informação confidencial da Instituição. 


\section{CONSIDERAÇÕES FINAIS}

De acordo com documentos analisados e dados coletados no decorrer desta pesquisa, constata-se uma preocupação, por parte das 10 (dez) Instituições de Ensino Superior possuidoras do curso de Turismo do Distrito Federal, em cumprir a Lei de Diretrizes e Bases da Educação e as Diretrizes Curriculares para os Cursos de Turismo.

Tal preocupação fica evidenciada na elaboração e na organização curricular, cuja oferta de disciplinas/matérias contemplam os conteúdos básicos, conteúdos específicos e conteúdos-práticos.

A abordagem diversificada de disciplina nos cursos é um fator positivo para atender à demanda do mercado, mas a oferta direcionada por área nos currículos não oferece ao aluno a oportunidade de ter mais de uma habilitação.

Percebe-se a inconsistência na oferta nos currículos quando o aluno tem em sua grade curricular apenas, e tão somente, uma habilitação, limitando-o às mudanças e tendências do mercado.

O currículo ideal para os cursos de Turismo, por causa do universo de oferta no mercado, seria aquele que a Instituição de Ensino Superior disponibilizasse ao aluno um número de créditos do núcleo obrigatório e formação geral nos primeiros semestres e, partir do $5^{\circ}$ ou $6^{\circ}$ semestre, o aluno pudesse optar pela dupla habilitação, ou duplo curso, a exemplo dos cursos de licenciatura da Universidade de Brasília.

Os cursos de Turismo ainda não participaram do Exame Nacional de Cursos, o Provão, nem e da Avaliação das condições de oferta. As avaliações são feitas pelo Ministério da Educação para verificação do controle de qualidade dos cursos, sendo solicitado, após estas avaliações, que as Instituições de Ensino invistam na qualificação de seu quadro docente, em bibliotecas, computadores e outros equipamentos de apoio instrucional, Portanto não há como avaliar as condições em que os cursos de Turismo se encontram no Distrito Federal.

Concluindo a pesquisa exploratória, verifica-se que, de acordo com a análise dos documentos e entrevistas apresentados, as grades curriculares das Instituições de Ensino Superior estão em consonância com as Diretrizes Curriculares aplicáveis aos cursos de Turismo.

Verifica-se também que as Instituições, apesar da grande maioria serem recentes no Distrito Federal, estão empenhadas na busca da melhoria na qualidade de seus cursos. 


\section{BIBLIOGRAFIA}

ANSARAH, M. G. Turismo como aprender e como ensinar. Vol. 1 e 3, SENAC, 1998.

ARBACHE, Jorge Saba. O mercado de trabalho na atividade econômica do turismo no Brasil. Editora Universidade de Brasília. Distrito Federal, 2001.

BARRETO, Margarida. Manual de iniciação ao estudo do turismo. 9a edição, Papirus, São Paulo.

BENI, Mário Carlos. Análise estrutural do turismo. São Paulo: Ed. SENAC, 2001.

BERTRAN, Paulo. História da terra e do homem no Planalto Central. 1989.

BRASIL. Diretrizes Curriculares Nacionais do Curso de Graduação em turismo. CNE/CES 288/2003.

COOPER, Chris. Educando os Educadores em Turismo: manual de educação em turismo e hospitalidade. São Paulo, Roca, 2001.

CUNHA, Regina Céli Oliveira. $21^{\circ}$ Reunião Anual da ANPEd, GT Currículo. Caxambu, 1998.

CURY, Carlos Roberto Jamil. Lei de Diretrizes e Bases da Eduçcação: Lei nº 9.394/96. $4^{a}$ edição. Rio de Janeiro: DP \& A, 2001.

DENKER, Ada de Freitas Maneti. Métodos e técnicas de pesquisa em turismo. 3 ed. São Paulo: Futura, 2000.

EMBRATUR. Evolução do turismo no Brasil - 1992-2002, 2003.

FARIA, Dóris e Carneiro, Kátia Saraiva. Sustentabilidade ecológica no turismo. Editora Universidade de Brasília. Distrito Federal. 2001.

LDB Lei de Diretrizes e Bases da Educação Nacional n 9.394/96, promulgada em 20 de dezembro de 1996, e sancionada em 23 de dezembro de 1996.

MOREIRA, Flávio Antonio e Silva, Tomaz Tadeu da. Currículo, Cultura e Sociedade.

SHIGUNOV, Alexandre Neto - Maciel, Lizate S. B. (Organizadores) Currículo e Formação Profissional nos cursos de turismo. São Paulo - Papirus, 2002.

TRIGO, Luiz Gonzaga Godoi ,(org.). Turismo - Como aprender, como ensinar - SENAC, São Paulo, 2001.

TRIGO, Luiz Gonzaga Godoi - A sociedade pós-industrial e o profissional em Turismo São Paulo - Papirus - 2001

TYLER, Ralph W. Principios básicos de currículo e ensino. Porto Alegre - Editora Globo 1981.

VELLASCO, Ana Maria de Moraes Sarmento. Manual de Orientações para a Produção de 
Textos Acadêmicos. 2003.

VERGARA, Sylvia Constant. Projetos e Relatórios de Pesquisa em Administração. São Paulo: editora Atlas, 1997.

WORLD TRAVEL TOURISM REVIEW (1991). "Indicators, trends and forecasts". Wallingford, Reino Unido: CAB International.

YAZIGI, Eduardo (org.) Turismo Espaço e Cultura - 2a edição, HUCITEC, São Paulo, 2001. 
10. ANEXOS 


\section{Anexo A - Entrevistas}

Entrevista sobre os cursos e currículos de graduação das Faculdades de Turismo no DF, realizada no período de novembro de 2003 a janeiro de 2004.

Profa Dra Cláudia Brochado, coordenadora de graduação do curso de Turismo do IESB, localizado na SGAS QUADRA 613/614 - Lotes 97 a 98, L2 Sul, realizada dia 04/12/2003, nas dependências da Faculdade.

\section{Pergunta $n^{\circ} 1$ - Quais são os objetivos gerais do curso de turismo do IESB?}

\section{Resposta:}

- Em primeiro lugar, a gente entende que por ser um curso de nível superior, o aluno precisa, antes de mais nada, ter uma visão ampla da sociedade, crescer enquanto cidadão, ter responsabilidade social, nesse sentido a gente oferece aquelas matérias do tronco comum de um curso da área de humanas que são as matérias básicas que vão ajudar justamente na formação do indivíduo que chega a ter um nível superior: filosofia, história, sociologia, economia e assim por diante, por outro lado a gente -sabe também é importante para este aluno dominar as ferramentas necessárias para atuar no mercado trabalho, chamadas habilidades e competências que tem sido hoje em dia questionadas dentro das diretrizes curriculares do MEC. Então ele vai ter muitos conhecimentos técnicos relacionados à profissão em si, então nosso objetivo é oferecer a esse aluno esses domínios, estes conhecimentos, aí, para que ele se torne um cidadão melhor, com uma responsabilidade social, com visão global da realidade do mundo onde ele está inserido e que ele seja um retorno do desenvolvimento responsável e sustentável do turismo no Brasil, então nosso curso está em sintonia com a LDB também que vai ta falando desta questão e também com as políticas de turismo governamentais que prevêem que é necessário que haja uma melhoria nos serviços oferecidos, e para isso os profissionais atuam na área e aqueles que estejam pensando em turismo e que sejam profissionais formados, que tenham uma formação teórica e consistente, não só técnico como seria por exemplo, os cursos só técnico do SENAC que oferece ali muitos cursos 
bons para aquilo que se propõe mas é o curso superior que vai capacitar alunos, resolver problemas, não ser só um vetor de transformação, ele não só vai constatar e vai trabalhar e prestar o serviço, ele vai verificar onde não está funcionando bem, ele vai propor mudanças, ai ser empreendedor, então é isso que a gente procura, e o nosso objetivo é formar esse profissional.

\section{2 - Como que o IESB realiza a interação entre a teoria e a prática?}

\section{Resposta:}

- "Pra começar, a gente incentiva muito os professores a estarem sempre trazendo exemplos que façam com que aquele conteúdo teórico seja mais facilmente visualizado pelo aluno. O nosso aluno tem muita facilidade de abstração de conhecimentos, então quando você apresenta os exemplos de uma forma mais prática daquela teoria que você ta ensinando ele tem muito mais condição de entender o que ele está dizendo e fazer as conexões, aí então já começa por aí essa nossa preocupação e ficamos sempre pedindo aos professores trabalharem com eles com "cases" ou casos que é importante trazer exemplos que ás vezes saem na mídia e discutir com eles casos concretos, reais ou não. Por outro lado, a gente incentiva também algumas atividades práticas para que o aluno possa trabalhar efetivamente com conteúdos, é o caso das matérias de planejamento que nós já fizemos, por exemplo, aqui um projeto que foi de parceria com 2 (duas) cidades: Paracatu e Niquelândia, fizemos inventário turístico da cidade, então isso é um trabalho prático que é algo até comum nos cursos de turismo estas atividades que são inventários de municípios. Outras coisas são saídas que eles fazem, para verificar as condições de um empreendimento com relação aos aspectos de sustentabilidade social, ambiental e etc. Quando eles vão fazer uma visita ao empreendimento, eles vão estar observando isso e fazendo relatório, observa se existe preocupação naquele estabelecimento com a questão ambiental, com o tratamento seletivo da questão do plano de manejo na utilização dos espaços, e etc. Então esta também é uma atividade que eles vão estar fazendo na prática. Depois nós temos também atividades relacionadas com a semana de turismo e hotelaria que muitas vezes eles trazem grupos para estarem aqui apresentando seus trabalhos, tanto de empreendimento quanto de grupos artísticos com manifestações culturais. Temos uma atividade aqui que é constante que é o "Café com artes" que faz parte da disciplina "Organização de eventos" que acontece todas as terças-feiras, eles organizam o evento 
aqui que acontece justamente neste espaço que você está vendo. O palco foi montado porque os eventos acontecem aqui na cantina e então os alunos já trouxeram de tudo aqui, muitos eventos relacionados a música e muitas outras coisas, então é uma outra atividade prática, ela é constante dentro de uma disciplina específica e assim, outras disciplinas que têm facetas mais práticas que oferece mais condição de desenvolver estas atividades práticas.

\section{Pergunta $n^{\circ} 3$ - Como é que é feita a avaliação dos alunos?}

\section{Resposta:}

“ - Na avaliação, sempre pedimos que os professores deixem muito claro no primeiro dia de aula, os critérios de avaliação que eles vão adotar, eles entram em sala de aula com o plano de curso que deve estar bem definido, e informam quais são os critérios de avaliação, é uma exigência, faz parte da nossa filosofia. O IESB tem essa tendência a ser muito rigoroso com algumas questões, dentre elas, com a questão disciplinar, a questão do celular é terminantemente proibido, tanto alunos como professores. É uma das exigências também é que o professor não dê só um tipo de avaliação, a gente acredita que a prova escrita é um instrumento importante porque é uma avaliação individual e outros também, como por exemplo os trabalhos em grupo, porque a gente sabe que é muito importante hoje em dia para o aluno desenvolver a capacidade de trabalhar em equipe, a gente sabe que qualquer profissional hoje em dia para ter sucesso ele tem que trabalhar em equipe, tem que saber dividir, ele tem que saber se satisfazer também com as vitórias dos outros, não só com as deles. Este é o profissional hoje em dia que se espera formar, não é aquele individualista que trabalha e quer todos os méritos para si, e não tenha a capacidade de dividir e trabalhar em equipe tem que saber dividir, ele tem que saber satisfazer também com as vitórias dos outros, não só com as deles. Este é o profissional hoje em dia que se espera, não é aquele individualista que trabalha para si e quer todos méritos para si e não tenha a capacidade de dividir e trabalhar em equipe, então este trabalho de equipe é muito importante, por isso a gente reforça e pede que existam outros tipos de avaliação e não apenas a prova individual. Mas a prova existe, agente até pede que façam em geral 2 (duas) avaliações escritas por bimestre, salvo algumas exceções porque são matérias que não tem perfil pra provas, elas são disciplinas mais práticas, como a matéria "Organização de Eventos", que os alunos vão desenvolver em evento, pode até também ter uma prova, 
mas o trabalho principal é um evento que eles vão organizar e outras, que são matérias que têm avaliações mais práticas. Concluindo, pedimos a diversificação, mas não abrimos mão da avaliação, a prova escrita.

\section{Pergunta $n^{\circ} 4$ - Qual percentual de evasão no curso de turismo do IESB?}

\section{Resposta:}

Eu não saberia dizer esse percentual, eu só sei que na nossa $1^{a}$ turma de formandos que aconteceu no mês de julho, formaram um número muito significativo de alunos, eu acho que não tínhamos nem 100 (cem) alunos no início do curso e a nossa $1^{\text {a }}$ turma tinha 60 alunos, então é um percentual muito grande de formandos, quer dizer também que o aluno não abandonou, às vezes o aluno reprovou em uma matéria, trancou o semestre e depois retornou e perdeu a turma. Além de ter uma baixa evasão o IESB recebe uma quantidade muito grande de pedidos de transferência, então todo semestre é uma quantidade muito grande de alunos que vem de fora, filhos de pessoas que são da área de turismo que vem pra Brasília, como filho de presidente de companhia aérea, filho de um dono de um grande hotel, muitos escolhem o IESB pra estudar, além dos pedidos de outras faculdades do DF. Tem alguns semestres que até é exagerado, dá muito trabalho, mas realmente faço muito esforço, porque aceito quase todos.

Profa Rose Mary Gonçalves, coordenadora de graduação do curso de Turismo da EuroAmericana, localizada na Av. das Nações, realizada dia 05/12/2003, nas dependências da Faculdade.

\section{Pergunta $n^{\circ} 1$ - Quais são os objetivos gerais do curso de turismo da Euro- Americana? Como é feita a interação entre a teoria e a prática?}

O objetivo geral é a idéia de formar um profissional justamente como eu comentei com você a história do foco, o nosso foco é formar pessoas para planejamento e gestão de todas as atividades do turismo, porque nós sentimos justamente em discussão com os profissionais da área, os turismólogos, quais são as necessidades, o que o mercado está 
pedindo, a idéia é o que o governo está solicitando, o que a academia está precisando, então essa idéia de voltarmos somente a um tipo de mercado é muito volátil, você está formando um profissional que daqui 4 anos, quando ele sair da faculdade ele está obsoleto, então a idéia é justamente ter uma formação profissional de "pensadores" da área do turismo, tanto na área de gestão como na área de planejamento, nosso objetivo é formar esse profissional com a visão um pouco mais ampla do que seria aquela História de realmente fazer com que o aluno tenha a percepção dessa necessidade de educação continuada, então quer dizer que, a partir do momento que ele termina o curso não é simplesmente, eu fiz e pronto acabou, ele tem que continuar, aí ele vai, a nossa idéia é que o curso dê uma visão geral que todas as áreas possíveis de atuação, para que o aluno tenha essa percepção de escolha da área que quer atuar e dessa necessidade de continuar atualizando-se, só que seu eu não formar um profissional com essa visão ele não consegue depois, na hora que ele termina, ele fala e agora, então a idéia é que ele seja agente dessa própria educação da construção do seu próprio conhecimento e aí, a partir disso, começa a responder a outra pergunta.

Outro exemplo é a prefeitura do Paranoá, ficaram sabendo do nosso trabalho e fizemos convênio com eles para realizar trabalho de campo em conjunto com a Faculdade Caiçaras . O estágio também são feitos com trabalhos de campo

\section{Pergunta $n^{\circ} 3$ - Como é que é feita a avaliação dos alunos?}

A avaliação é feita com os trabalhos interdisciplinares, tem acompanhamento de uma banca durante todos os trabalhos, momentos de orientação, isso já faz parte do processo de avaliação, acompanhamento dos grupos, conversando com os alunos, tem o retorno imediato, identificando as dificuldades pra poder estar recuperando e vivenciando o interesse, além das provas formais que fazem parte do regimento da faculdade, os relatórios são contados como nota, e isso é feito a cada início de semestre, os professores passam pro aluno e ele já sabe do processos 


\section{Pergunta n 4 - Qual percentual de evasão no curso de turismo da Euro-Americana?}

Durante um tempo, no começo do curso, houve uma evasão muito grande, eu não estava aqui na época, mas acredito que foi devido à falta de estrutura, era um curso novo no mercado, a partir do momento em que criamos este laboratório, a vinda da Prof. Janice pra cá, a implementação da interdisciplinaridade melhoru muito. Mas a evasão é normal, acredito que 10\% no máximo, e inclusive a gente está recebendo alunos de outras faculdades, a evasão é muito maior pela questão econômica, as pessoas não estão podendo pagar, trancam porque não estão dando conta de pagar e não por causa do curso, e às vezes tranca e volta a cursar novamente, e os alunos muitas vezes voltam quando podem pagar e isso é bom. A evasão está ligada a parte financeira e não ao curso propriamente dita.

Os alunos já estão sabendo que, recentemente foi feita uma reunião para a mudança da grade curricular. Conversei com todas as salas, e procurei saber e ouvir os principais problemas dos alunos e professores o que estava bom e foi muito importante este processo de construção porque não foi uma coisa que foi feita com meia dúzia de pessoas, e pronto elaborou um plano, os alunos estão da bando disso, sabem que vai haver mudança para melhorar o curso, e eles estão sentindo a mudança, . Estamos propondo fazer convênios com embaixadas, com faculdades como a FTB, e isso é importante para a interdisciplinaridade, porque é uma forma dos alunos compartilharem experiências. O trabalho que foi feito com a Faculdades Caiçaras foi muito bom, porque o inventário no Paranoá são eles que realizam é a área deles, tivemos uma resistência, mas perceberam que pode acontecer isso na vida profissional, de repente são convidados a fazer levantamento de uma cidadezinha e, você vai falar sobre todo o planejamento e a pessoa vai falar que você está fazendo coisa que não existe, não tem nada a ver com a realidade aqui, aprendem a ter jogo de cintura,por isso que é importante este percepção e este contato com aluno de outras instituições, outros perfis, outras idéias está sendo muito importante, A idéia é essa, e também estamos trabalhando para que aconteça um fórum entre todas as faculdades vai ser muito bom para os alunos, haverá troca e com certeza haverá crescimento para todo mundo. 
Entrevista com o Prof. Mauro Castro de Azevedo e Souza - M.Sc. Coordenador do Curso de Turismo, Centro Universitário de Brasília - UniCEUB, localizado na EQN 707/907, dia 29/01/2004, obtida por meio eletrônico,.

\section{Pergunta n 1 - Quais são os objetivos gerais do curso de turismo do UniCEUB?}

\section{Resposta:}

Formar profissional competente em Turismo, com as capacidades técnicas e éticas necessárias. Formar um cidadão, no sentido pleno de um indivíduo participante de uma sociedade e solidário com seus membros, com consciência da complexidade do mundo atual. Preparar empreendedores capaz de atuar em uma sociedade globalizada, que seja capaz de fazer frente às exigências de mercado dentro ou fora do Brasil.

Objetivos específicos:

O currículo do curso de Turismo do UniCEUB está fundamentado, além das bases filosóficas que são comuns a todos os cursos da Instituição, nos seguintes objetivos específicos:

- Promover o pluralismo de idéias

- Gerar respeito à liberdade e apreço à tolerância

- Permitir vinculação entre a educação acadêmica e a prática profissional

- Formar profissionais abertos a novas idéias e capazes de contribuir para a melhoria da sociedade, de forma a estar sempre comprometidos com a dignidade do ser humano

- Acompanhar discussões em torno das mudanças na profissão do bacharel em turismo

- Otimizar a capacidade de criar e propor soluções mesmo considerando dificuldades inerentes à conjuntura turística em um mundo globalizado

- Desenvolver atividades de ensino-aprendizagem de modo que o aluno seja sujeito da ação pedagógica

- Estimular o espírito empreendedor do aluno

- Estimular a pesquisa e a investigação científica

- Formar egresso que mantenham o desejo de permanente aperfeiçoamento cultural e profissional 
- Estímulo ao conhecimento dos problemas referentes ao turismo, sua realidade, sua política e seus paradigmas do mundo presente, no âmbito regional, nacional e internacional

- Estímulo à capacidade e flexibilidade de pensamento para associar a prática escolar à prestação de consultoria na área de turismo, estabelecendo com a comunidade uma relação de reciprocidade.

Pergunta $n^{\circ} 2$ - Como que o UniCEUB realiza a interação entre a teoria e a prática?

\section{Resposta:}

Temos um projeto de Interpretação e planejamento turístico municipal. Um trabalho interdisciplinar que atinge 6 períodos do curso e interage realidade local com teoria em sala de aula.

\section{Pergunta $n^{\circ} 3$ - Como é que é realizada a avaliação dos alunos?}

\section{Resposta:}

Isto é decidido pelo professor da disciplina, a única coisa regulamentada pelo regimento é que os professores devem aplicar duas avaliações, no mínimo por semestre.

\section{Pergunta $n^{\circ} 4$ - Qual percentual de evasão no curso de turismo do UniCEUB?}

\section{Resposta:}

Temos evasão como qualquer instituição. No entanto, essa informação ela é confidencial da instituição. Mas, está na média do mercado. 